\title{
Speculative Capital and Currency Carry Trades
}

\author{
Petri Jylhä and Matti Suominen*
}

First version: April 18, 2008

Current version: June 1, 2010

\begin{abstract}
In this paper, we study a two-country general equilibrium model with partially segmented financial markets, where hedge funds emerge endogenously. Empirically, we show that the hedge fund investment strategy predicted by our model, which we call the "risk-adjusted carry trade" strategy, explains more than $16 \%$ of the overall hedge fund index returns and more than $33 \%$ of the fixed income arbitrage sub-index returns. The flow of new money to hedge funds affects market interest rates, exchange rates, and both the hedge funds' contemporaneous and expected future returns as predicted by the model.
\end{abstract}

Key words: Hedge funds, currency speculation, carry trades.

JEL: G15, F31, E43.

\footnotetext{
* Both authors are from the Aalto University, Helsinki. The contact is Matti Suominen. Address: PL 1210, Helsinki 00101, Finland. E-mail: matti.suominen@hse.fi, tel.: +358-50-5245678, fax: +358-9-43138678. We are grateful to Jussi-Pekka Lyytinen for initiating our interest in currency carry trade research. This paper was previously circulated under the title "Arbitrage Capital and Currency Carry Trade Returns." We thank Richard Levich (the referee), Rui Albuquerque, Peter Christoffersen, Robin Greenwood, Denis Gromb, Harald Hau, Markku Lanne, Massimo Massa, Stefan Nagel, Vasant Naik, Robert Kosowski, Dimitri Vayanos, Adrien Verdelhan and the seminar participants at INSEAD, Helsinki School of Economics, Bank of Finland, 2009 AFA Meetings in San Francisco, Spring 2008 Adam Smith Asset Pricing Conference at LSE, 2009 SED meetings in Istanbul, and INFINITI 2009 for comments. Jylhä thanks the Finnish Foundation for Advancement of Securities Markets and both authors thank the Okobank Group Research Foundation for financial support.
} 


\section{Introduction}

In this paper, we study currency speculation by hedge funds. In the theoretical part of the paper, we study a two-country general equilibrium model with partially segmented financial markets, where hedge funds emerge endogenously. As in Fama and Farber (1979), the interest rates and the foreign exchange rate are determined by the two countries' inflation risks and money supplies. In our model, some of the agents are restricted, and can invest only in domestic fixed income securities, while others, speculators, can borrow and invest freely in all available fixed income securities. When the number of speculators is small, and the two countries' inflation shocks are highly correlated, all speculators invest in a hedge fund that borrows from the country with the lower Sharpe ratio for fixed income securities and invests in the country with the higher Sharpe ratio. We refer to this strategy as the "risk-adjusted carry trade" investment strategy. When the barriers to international investments are reduced, more investors invest in the hedge fund. The flow of new money to the hedge fund affects market interest rates, the exchange rate, the hedge fund's leverage, and both its contemporaneous and expected future returns. ${ }^{1}$

Empirically, we test the predictions of the model using a sample of 11 currencies and 30 years of data. First, our results show that hedge funds do, in fact, engage in the type of currency speculation that our model predicts. The returns from a simple investment strategy, where long and short currency portfolios are formed on the basis of the rankings of the currencies by their expected Sharpe ratios, explains more than $16 \%$ of the overall hedge fund index returns and more than $33 \%$ of the fixed income arbitrage sub-index returns. The explanatory power of our strategy's returns is significant even when controlling for the seven Fung and Hsieh (2004) factors that are commonly used to explain hedge fund returns. Under certain assumptions, the investment strategy predicted by

${ }^{1}$ The foreign exchange market has historically been partly segmented due to various barriers in foreign exchange transactions. Also, behavioral barriers, for instance due to lack of knowledge or overestimation of risks, may be important. 
our model is identical to the simple carry trade investment strategy, where the long and short portfolios are formed on the basis of interest rate and not Sharpe ratio rankings. Empirically, the returns and portfolio compositions of these two strategies are highly correlated and the returns from the simple carry trade strategy explain equally well the returns of various hedge fund indexes.

Second, we show that the increased hedge fund assets under management (AUM) and positive inflows of funds to hedge funds decrease the expected returns from the two carry trade strategies, and decrease interest rates in high Sharpe ratio (high interest rate) countries while increasing the interest rates in low Sharpe ratio (low interest rate) countries. In addition, the flow of funds to hedge funds affects exchange rates, appreciating (depreciating) the exchange rate of the high (low) Sharpe ratio, or high (low) interest rate, currencies. In the fall of 2008, there was a large outflow of funds from the hedge fund industry. In accordance with our theoretical predictions and empirical results, the effect was opposite to hedge fund inflows and as a result of the large outflows from the funds, the low Sharpe ratio (low interest rate) currencies appreciated significantly relative to the high Sharpe ratio (high interest rate) currencies. ${ }^{2}$

Our paper is connected to an emerging stream of literature on partial market segmentation and limited speculative capital. Gromb and Vayanos (2002) study a segmented market model, similar to ours, where some investors are only allowed to invest in one of the two risky assets, whereas others are allowed to invest in both. In Vayanos and Vila (2009), fixed income markets are endogenously segmented by investors' differing preferences for different maturities (preferred habitat), while a limited number of arbitrageurs act as a market integrating force. Their model is tested empirically in Greenwood and Vayanos (2008). In these papers, the capital engaged in speculation is limited by either speculators' financing constraints or their risk aversion. Other

\footnotetext{
${ }^{2}$ The currency movements in the fall of 2008 were extreme: For instance, the currency with the lowest interest rate, the Japanese yen, appreciated relative to the currency with the highest interest rate, the British pound, by $40 \%$ in just a few months.
} 
papers that study models with limited speculative capital include DeLong, Shleifer, Summers, and Waldmann (1990), Shleifer and Vishny (1997), Kyle and Xiong (2001), and Brunnermeier and Pedersen (2009). One recent paper in this strand of literature-which is very close in spirit to ours and deals with currency speculation - is Brunnermeier, Nagel, and Pedersen (2009). Empirically, they show that carry trades are subject to currency crash risk, i.e., the exchange rate movements of carry trade portfolios are negatively skewed. They argue that the skewness in foreign exchange rates follows from temporary changes in the availability of funding liquidity to speculators. A temporary reduction in funding liquidity results in a rapid unwinding of traders' positions and thus leads to abrupt changes in exchange rates, which go against the carry traders. This risk, the authors argue, is a major factor affecting traders' willingness to enter into these "risk arbitrage" positions and arbitrage away the positive returns to carry trades. Their risk-based explanation of carry trade returns complements ours and our finding that hedge fund flows affect both contemporaneous and expected carry trade returns., 4

Second, our paper is related to the literature on carry trade profitability, such as Burnside, Eichenbaum, Kleshchelski, and Rebelo (2006) and Lustig, Roussanov, and Verdelhan (2008). We argue, and provide evidence, that one driver of the profitability of the simple carry trade strategy is the number of funds engaging in carry trades. Third, our results are related to the literature on the forward premium puzzle, that is, the observed failure of the uncovered interest rate parity (see, e.g., Bilson, 1981; Fama, 1984; Froot and Thaler, 1990; Bekaert, 1996; Engel, 1996; or Bansal and Dahlquist, 2000). ${ }^{5}$ In line with Fama and Farber (1979) and Grossman (1995), our

\footnotetext{
${ }^{3}$ One additional related paper is Gârleanu, Pedersen, and Poteshman (2009), which examines the pricing of different option contracts when market makers' ability to engage in arbitrage is limited.

${ }^{4}$ Also related is the earlier literature on segmented markets and covered interest rate parity. See, for instance, Keynes (1923), Einzig (1961), and Grubel (1965). See also Prachowny (1970), who studies deviations from covered interest rate parity in a model with less than infinitely elastic supply and demand of forward currency.

${ }^{5}$ Other relevant papers on this topic include Cumby (1988), Backus, Gregory, and Telmer (1993), Bekaert, Hodrick, and Marshall (1997), Hollifield and Uppal (1997), Mark and Wu (1998), Roll and Yan (2000), Backus, Foresi, and Telmer (2001), Lyons (2001), Gourinchas and Tornell (2004), Lustig and Verdelhan (2007), Albuquerque (2008), Farhi and Gabaix (2008), Wagner (2008), Alvarez, Atkenson, and Kehoe (2009), Bansal and Shaliastovich (2009), Burnside,
} 
results suggest that the failure of the uncovered interest rate parity is due to compensation for risks. In addition, however, our evidence suggests that the historically observed large returns to strategies exploiting the forward premium puzzle, such as carry trades, were due to segmented markets and the gradual integration of fixed income securities markets during the past few decades. ${ }^{6}$

The rest of the paper is organized as follows: In Section 2, we present the model and in Section 3 the theoretical results. Sections 4-8 contain the empirical part of the paper. We present the data in Section 4. In Section 5, we study whether hedge funds are involved in currency speculation. In Section 6, we study how hedge fund flows affect the returns from currency speculation. In Section 7, we look at the effect of hedge fund flows on interest rates, while in Section 8 we examine their effect on exchange rates. Section 9 concludes the paper.

\section{The model}

Our model combines elements from Fama and Farber (1979) and Bacchetta and van Wincoop (2006). Our main point of departure from the former is to assume partially segmented financial markets. Consider a model with two countries $i \in\{A, B\}$. In both countries, there are $N$ citizens, where $N$ is normalized to one. The citizens produce and consume a single commodity and, as in Bacchetta and van Wincoop (2006), use money in the production of this commodity. Money used in production in period $t$ is recovered at its full nominal value at the beginning of the next period $t+1$. In particular, we assume that country $i$ 's citizens' production function generates $f\left(m_{i, t}\right)$

Eichenbaum, and Rebelo (2009), Burnside, Han, Hirshleifer, and Wang (2010), Plantin and Shin (2010), and Verdelhan (2010).

${ }^{6}$ Finally, our paper is also related to the hedge fund literature. Baquero and Verbeek (2009) and Wang and Zheng (2008) show a positive contemporaneous relation between hedge fund flows and returns and Wang and Zheng (2008) and Avramov, Barars, and Kosowski (2009) find evidence of a negative relation between flows and future returns. Our study offers one channel through which flows have a positive return effect on the existing positions but decrease the future expected returns. Our results also complement those of Fung and Hsieh (2000) and Ding, Getmansky, Liang, and Wermers (2007) who study the impact of hedge funds on the financial markets as a whole. 
goods in period $t+1$, where $m_{i, t}$ denotes agents' real money holdings of country $i$ 's currency in period $t$. We assume that $f\left(m_{i, t}\right)$ is increasing and concave in $m_{i, t}$.

The purchasing power of country $i$ 's money in period $t$ is denoted by $\pi_{i, t}$, so that $M$ units of country $i$ 's currency have a real purchasing power of $m_{i, t}=M \pi_{i, t}$. The future purchasing power of money is random at time $t$, so that given information available at time $t$,

$$
\left[\begin{array}{l}
\tilde{\pi}_{i, t+1} \\
\tilde{\pi}_{j, t+1}
\end{array}\right] \sim N(\mu ; \Sigma) \text {, where } \mu=\left[\begin{array}{c}
E_{t} \tilde{\pi}_{i, t+1} \\
E_{t} \tilde{\pi}_{j, t+1}
\end{array}\right] \text { and } \Sigma=\left[\begin{array}{cc}
\sigma_{i}^{2} & \rho \sigma_{i} \sigma_{j} \\
\rho \sigma_{i} \sigma_{j} & \sigma_{j}^{2}
\end{array}\right] \text {. }
$$

Here, $E_{t}$ refers to the expectation operator conditioned on time $t$ information set and a tilde on top of a variable is used to denote a random variable. ${ }^{7}$

Besides money, there are two other storage technologies in each country: first, a riskfree asset that pays a periodic constant real return $r_{f}$, and second, a one-period default free zerocoupon bond, sold at a real market price $p_{i, t}$, that pays one unit of country $i$ 's nominal currency at time $t+1$. The risk in this asset comes from the uncertain purchasing power of money in period $t+1$. Both risky assets are in zero net supply. Like Fama and Farber (1979), we assume that all consumers first hedge their money holdings in the bond market, and only then look at their investments into bonds. In this case, the effective supply of zero-coupon bonds in the market, denoted in country $i$ 's currency, is country $i$ 's money supply, $\bar{M}_{i}$.

Our consumers are myopic. Like Bacchetta and van Wincoop (2006), we assume overlapping generations of agents, who live for two periods, invest when they are young and

\footnotetext{
${ }^{7}$ We take the expected future purchasing power of money $E_{t} \tilde{\pi}_{i, t+1}$ as exogenous to the model, as it is driven, for example, by future money supply.
} 
consume when they are old. ${ }^{8}$ Before dying, they sell their money holdings to the next generation. To obtain closed form expressions for asset prices, we assume that period $t$ investors value their random period $t+1$ consumption using a constant absolute risk aversion (CARA) utility function, $u\left(\widetilde{c}_{t+1}\right)=-E_{t} e^{-a \widetilde{c}_{t+1}}$, where $a$ denotes the parameter of risk aversion and $\widetilde{c}_{t+1}$ their random consumption in period $t+1$. Furthermore, let us denote by $b_{i, t}$ the quantity of country $i$ 's nominal zero-coupon bonds, with a face value of one, that an agent purchases (or sells) in period $t$ in addition to his short position in country $i$ 's bonds, that comes from hedging his currency holdings. ${ }^{9}$ Similarly, let $b_{j, t}$ refer to purchases of country $j$ 's bonds.

We assume that the financial markets are segmented in the following way: a fraction $\left(1-k_{i}\right)>0$ of country $i$ 's investors have prohibitively high transaction costs of investing abroad, i.e., to hold money or interest-bearing securities in a foreign currency. Fraction $k_{i}$ of country $i$ 's investors, on the other hand, are unrestricted. We call the restricted investors "domestic investors" and the unrestricted ones, "speculators." In both countries, there is a one-time cost $\phi$ of becoming a speculator and the number of speculators is determined endogenously. ${ }^{10}$ In contrast to the financial markets, there are no barriers, such as tariffs or transportation costs, in the product market. ${ }^{11}$

8 Other papers that assume myopic agents in dynamic asset pricing models include Campbell, Grossman, and Wang (1993) and Vives (1995).

${ }^{9}$ If an agent's real money holdings are $m_{i, t}$, we assume he sells short $M_{i, t}=m_{i, t} / \pi_{i, t}$ zero-coupon bonds to hedge his money holdings before considering any other investments into bonds.

${ }^{10}$ In our model, $\phi$ proxies for several different types of real and informational barriers to becoming a currency trader. Examples of these are all regulatory barriers, the direct costs from setting up a currency account, with a facility for foreign currency borrowing, and the costs from acquiring information on the expected returns and risks related to currency trading. In the theoretical part below, we study what happens when $\phi$ decreases. This is motivated by the observation that the barriers to currency trading most likely decreased during our sample period, i.e., during the last three decades. This, we argue, occurred due to 1) loosening of foreign exchange controls and the associated financial market integration, 2) the emergence of currency hedge funds that are marketed to an ever-increasing fraction of the population, 3) the globalization of media that has increased awareness of currency trading opportunities, and 4) academic research that has pointed out the failure of the uncovered interest rate parity and provided investors with estimates of the historical returns to currency carry trades.

${ }^{11}$ This assumption is made for simplicity and because of the focus of the paper. Including some barriers in the product market, such as tariffs and transportation costs, and studying the product market flows, and deviations from purchasing power parity (PPP), might bring some additional economic insights but would result in a more complicated model. 
Therefore, assuming period $t$ investors are endowed with a real wealth $w_{t}$, after choosing whether to become a speculator, country $i$ 's investors at time $t$ maximize:

$\max _{m_{i, t}, b_{i, t}, b_{j, t}} u\left(\widetilde{c}_{t+1}\right)=-E_{t} e^{-a \widetilde{c}_{t+1}}$

st. $\left\{\begin{array}{l}\widetilde{c}_{t+1}=\left(w_{t}-m_{i, t}+p_{i, t} m_{i, t} / \pi_{i, t}-I_{s} \phi\right)\left(1+r_{f}\right)+f\left(m_{t}\right)+b_{i, t}\left(\tilde{\pi}_{i, t+1}-p_{i, t}\left(1+r_{f}\right)\right)+b_{j, t}\left(\tilde{\pi}_{j, t+1}-p_{j, t}\left(1+r_{f}\right)\right) \\ b_{j, t} \mid \leq x .\end{array}\right.$

Here, $I_{S}$ is an indicator function that takes the value of one if and only if the investor is a speculator. The second constraint in the agents' maximization problem is related to financial market segmentation as follows: for domestic investors, $x=0$, while for speculators, $x=\infty$. Equilibrium prevails when each agent's action maximizes his expected utility. Finally, note that country $i$ 's citizens do not benefit from country $j$ 's currency in their production activities.

\section{Equilibrium and model predictions}

\subsection{Equilibrium}

There are no restrictions in the product market. Therefore, for all currency transactions, purchasing power parity (PPP) implies that the period $t$ exchange rate, at which country $j$ 's currency can be exchanged to country $i$ 's currency, is:

$$
S_{t}^{i / j}=\frac{\pi_{j, t}}{\pi_{i, t}}
$$

Define $M_{i, t}^{d}$ as the per capita supply of country $i$ 's zero-coupon bonds that must, in equilibrium, be purchased by the domestic investors of country $i$ at time $t$. Here, as well as below, 
we use a superscript $d$ to denote a domestic investor and a superscript $s$ to denote a speculator. In other words, if the speculators buy $\left(k_{i}+k_{j}\right) b_{i, t}^{s}$ units of country $i$ 's bonds, we define $M_{i, t}^{d}$ as:

$$
M_{i, t}^{d}=\frac{\bar{M}_{i}-\left(k_{i}+k_{j}\right) b_{i, t}^{s}}{1-k_{i}}
$$

Here, we have assumed, as we show later to be the case, that speculators from both countries hold identical bond portfolios. The sub-index $i$ in $b_{i, t}^{s}$ refers to the country in whose currency the investment is made. Now, setting $x=0$ in (2), taking expectations and the first-order condition of (2) with respect to domestic investors' bond holdings, $b_{i, t}^{d}$, and using the market clearing condition, $b_{i, t}^{d}=M_{i, t}^{d}$, we obtain that the price of the zero-coupon bond, $p_{i, t}$, in country $i$ at time $t$ is:

$$
p_{i, t}=\frac{E_{t} \tilde{\pi}_{i, t+1}-a \sigma_{i}^{2} M_{i, t}^{d}}{1+r_{f}} .
$$

The expected real return from investing in the nominal bonds, i.e., the equilibrium real interest rate, $r_{i, t}$, is:

$$
r_{i, t}=\frac{E_{t} \tilde{\pi}_{i, t+1}-p_{i, t}}{p_{i, t}}=\frac{r_{f}+a M_{i, t}^{d} \sigma_{i}^{2} / E_{t} \tilde{\pi}_{i, t+1}}{1-a M_{i, t}^{d} \sigma_{i}^{2} / E_{t} \tilde{\pi}_{i, t+1}} .
$$

The standard deviation of the real return from investing in nominal bonds of country $i$ is $\sigma_{i} / p_{i, t}$. Therefore, the Sharpe ratio for the real returns from bond investments is:

$$
S R_{i, t}=\frac{r_{i, t}-r_{f}}{\sigma_{i} / p_{i, t}}=a M_{i, t}^{d} \sigma_{i}
$$


These results show that the bond price (interest rate) is decreasing (increasing) in the parameter of risk aversion, $a$, inflation risk, $\sigma_{i}$, and the per capita supply of bonds in the domestic market, $M_{i, t}^{d}$. In the case of an autarky, where $k_{A}$ and $k_{B}$ are zero, $M_{i, t}^{d}=\bar{M}_{i}$, the local money supply. In such perfectly segmented markets, the Sharpe ratio for bonds is higher in the country with the higher per capita inflation risk, $\bar{M}_{i} \sigma_{i}{ }^{12}$ Let us denote by $H$ the country with the higher per capita inflation risk and by $L$ the country with the lower per capita inflation risk. In the case of autarkies, the higher Sharpe ratio in country $H$, as compared to country $L$, is necessary to attract sufficient investment into the risky bonds of country $H$, in order to clear the market, despite the higher amount of risk being sold.

Let us now look at the speculators' problem. The first order condition of (2) with respect to the speculators' investment into country $i$ 's bonds, ${ }_{i, t}^{s}$, implies:

$$
b_{i, t}^{s}=\frac{E_{t} \tilde{\pi}_{i, t+1}-p_{i, t}\left(1+r_{f}\right)-b_{j, t}^{s} a \rho \sigma_{i} \sigma_{j}}{a \sigma_{i}^{2}} .
$$

Again, the $i$ and $j$ sub-indexes refer to the currency in which the investment is made. Using (4) and (5) in (8), we can now solve for the equilibrium bond holdings. Solving the set of equations, we obtain that, in equilibrium, all speculators hold

$$
b_{i}^{s^{*}}=\frac{\bar{M}_{i} \sigma_{i}\left(1+k_{i}\right)-\bar{M}_{j} \sigma_{\mathrm{j}} \rho\left(1-k_{i}\right)}{\sigma_{i}\left(\left(1-\rho^{2}\right)\left(1+k_{j} k_{i}\right)+\left(1+\rho^{2}\right)\left(k_{j}+k_{i}\right)\right)}
$$

${ }^{12}$ Here, per capita inflation risk simply refers to the total amount of inflation risk in the money supply of a given currency divided by the number of investors in that country. This is the amount of inflation risk that each investor must carry in equilibrium in an autarky. 
of country $i$ 's bonds, while the domestic investors hold

$$
b_{i}^{d^{*}}=M_{i}^{d^{*}}=\frac{\bar{M}_{i}-\left(k_{i}+k_{j}\right) b_{i}^{s^{*}}}{1-k_{i}}=\frac{\bar{M}_{i} \sigma_{\mathrm{i}}\left(1+k_{i}-\rho^{2}+\rho^{2} k_{j}\right)+\bar{M}_{j} \sigma_{\mathrm{j}} \rho\left(k_{i}+k_{j}\right)}{\sigma_{\mathrm{i}}\left(\left(1-\rho^{2}\right)\left(1+k_{j} k_{i}\right)+\left(1+\rho^{2}\right)\left(k_{j}+k_{i}\right)\right)}
$$

of such bonds. The asterisk is used to denote an equilibrium value. Using (10) in Eqs. (5), (6) and (7) gives us an easy characterization of the equilibrium interest rates, bond prices, and the Sharpe ratios of bonds in our economy.

Given (3), the exchange rate is determined by the purchasing power of the two currencies as follows: Taking the first-order condition of (2) with respect to $m_{i, t}$, we obtain that for both the speculators and the domestic investors:

$$
p_{i, t}=\left[1-\frac{\frac{\partial f\left(m_{i, t}\right)}{\partial m_{i, t}}}{\left(1+r_{f}\right)}\right] \pi_{i, t}=\left[1-\frac{\frac{\partial f\left(\bar{M}_{i} \pi_{i, t}\right)}{\partial \pi_{i, t}}}{\bar{M}_{i}\left(1+r_{f}\right)}\right] \pi_{i, t} \equiv g\left(\bar{M}_{i, \pi_{i, t}}\right) .
$$

Recall that $f\left(m_{i, t}\right)=f\left(\bar{M}_{i} \pi_{i, t}\right)$ is an increasing and concave function of $m_{i, t}$. This implies that it is also an increasing and concave function of $\pi_{i, t}$. Assuming that inflation risk is small enough so that country $i$ 's bond price (5) is positive, this implies that $g\left(\bar{M}_{i}, \pi_{i, t}\right)$ is a strictly increasing function of $\pi_{i, t}$, so that for every $\bar{M}_{i}$, it has an inverse function $g^{-1}\left(\bar{M}_{i}, p_{i, t}\right)=\pi_{i, t}$ that is strictly increasing in $p_{i, t}$. The exchange rate can now be stated as a function of the two countries zero-coupon bond prices as follows: 


$$
S_{t}^{i / j}=\frac{\pi_{j, t}}{\pi_{i, t}}=\frac{g^{-1}\left(\bar{M}_{j}, p_{j, t}\right)}{g^{-1}\left(\bar{M}_{i}, p_{i, t}\right)} .
$$

Let us now look at the determination of the number of speculators. As $k_{i}<1$ by assumption, it must be that the benefit of becoming a speculator is less than or equal to the cost of becoming one. In other words,

$$
\frac{u_{i}\left(\widetilde{c}_{t+1}^{d}\right)}{u_{i}\left(\widetilde{c}_{t+1}^{s}\right)}=\frac{e^{-b_{i}^{d}\left[E_{t} \pi_{i, t+1}-p_{i, t}\left(1+r_{f}\right)\right]+\frac{a}{2} b_{i}^{d^{2}} \sigma_{i}^{2}}}{e^{-b_{j}^{s}\left(E_{t} \pi_{j, t+1}-p_{j, t}\left(1+r_{f}\right)\right)-b_{i}^{s}\left(E_{t} \pi_{i, t+1}-p_{i, t}\left(1+r_{f}\right)\right)+\frac{a}{2}\left(b_{i}^{s^{2}} \sigma_{i}^{2}+b_{j}^{s^{2}} \sigma_{j}^{2}+2 b_{i}^{s} b_{j}^{S} \rho \sigma_{i} \sigma_{j}\right)+\phi(1+r)}} \leq 1 .
$$

Using (5) and (10), we can rewrite (13) as:

$$
-\frac{a}{2} b_{i}^{d^{2}} \sigma_{i}^{2}+a b_{j}^{s} b_{j}^{d} \sigma_{j}^{2}+a b_{i}^{s} b_{i}^{d} \sigma_{i}^{2}-\frac{a}{2}\left(b_{i}^{s^{2}} \sigma_{i}^{2}+b_{j}^{s^{2}} \sigma_{j}^{2}+2 b_{j}^{s} b_{i}^{s} \rho \sigma_{i} \sigma_{j}\right) \leq \phi(1+r) .
$$

Furthermore, Eqs. (13) and (14) must hold as strict equalities when $k_{i}>0$. From (14), it is easy to see that, as the condition is symmetric apart from the first term, the first speculators come from country $L$, as for an arbitrary small number of speculators $b_{i}^{d} \approx \bar{M}_{i}$ and $\bar{M}_{H} \sigma_{H}>\bar{M}_{L} \sigma_{L}$. Speculators from country $H$ enter only after $M_{L}^{d} \sigma_{L}=M_{H}^{d} \sigma_{H}$, or alternatively, given (7), when the Sharpe ratios of the bonds in the two countries are equal. We have now completed the characterization of the equilibrium.

\subsection{Hedge funds, hedge fund flows, interest rates, and exchange rates}

As we demonstrate below, in segmented markets, the speculators invest in a hedge fund. Let us start by defining the following two critical parameters: 


$$
\bar{\rho} \equiv \frac{\bar{M}_{L} \sigma_{L}}{\bar{M}_{H} \sigma_{H}}
$$

and

$$
\bar{k}_{L} \equiv \frac{\bar{M}_{H} \sigma_{H} \rho-\bar{M}_{L} \sigma_{L}}{\bar{M}_{H} \sigma_{H} \rho+\bar{M}_{L} \sigma_{L}} .
$$

For reasons provided in Proposition 1, we call $\bar{\rho}$ the minimal level of inflation risk correlation to induce speculation and $\bar{k}_{L}$ the minimal degree of segmentation needed to induce speculation.

We now move on to our propositions, which are proved in Appendix A.

Proposition 1. When correlation between inflation shocks is high enough, $\rho>\bar{\rho}$, and the markets are sufficiently segmented, $k_{L}<\bar{k}_{L}$, the speculators' portfolio is a "currency hedge fund" with a short position in currency $L$ and a long position in currency $H$. The expected returns to the speculators' hedge fund are positive. The leverage in the speculators' hedge fund, as defined by $-b_{L}^{s^{*}}$, approaches infinity when $\rho \rightarrow 1$ and $\max \left\{k_{L}, k_{H}\right\} \rightarrow 0$. The leverage decreases as the number of speculators increases.

Here, as well as below, we refer to the speculators' collective portfolio as a hedge fund when it contains both short and long positions in currencies. As all speculators hold identical portfolios, it is as if they all invested their wealth in the same fund. It is interesting to note that in our model the speculators' fund is a hedge fund only in sufficiently segmented markets, i.e., when market segmentation exceeds the minimal degree of segmentation needed to induce speculation 
(i.e., when $k_{L}<\bar{k}_{L}$ ). In more integrated markets, where $k_{L}>\bar{k}_{L}$, the speculators' investments are "long only." It is intuitive that there are no hedge funds in highly integrated markets. In perfectly integrated markets, both high and low inflation risk currencies are part of the global market portfolio that all agents hold in some positive quantities in equilibrium, as in Fama and Farber (1979).

Proposition 2. Assume $\rho>\bar{\rho}$ and $k_{L}<\bar{k}_{L}$. A reduction in $\phi$, the cost of becoming a speculator, leads to an increase in the number of speculators (which is equivalent to the flow of assets to the hedge fund), the convergence of the Sharpe ratios of the two countries' domestic bonds, and a decrease in the expected future returns to the speculators' hedge fund. A decrease in $\phi$, through an increase in the number of speculators, leads to a rise in $r_{L}$ and a decrease in $r_{H}$, a rise in bond price $p_{H}$, and a decrease in bond price $p_{L}$, and an increase in the exchange rate $S^{L / H}=\pi_{H} / \pi_{L}$. An increase in the number of speculators in period t affects positively the contemporaneous returns to the period t-1 speculators' hedge fund.

As Proposition 2 shows, an increase in the number of speculators affects interest rates and brings the two countries' real interest rates and zero-coupon bond prices closer to each other. As bond prices drive the real purchasing power of the currencies, the exchange rate (12) is also affected. The interest rates and the exchange rate move toward values that they would have in an integrated economy with better risk sharing.

Hedge funds have commonly been associated with simple currency carry trades (see, e.g., Galati, Heath, and McGuire, 2007), where the investors borrow in the low interest rate currency and invest in the high interest rate currency. When 


$$
\operatorname{argmax}\left\{M_{A}^{d} \sigma_{A}, M_{B}^{d} \sigma_{B}\right\}=\operatorname{argmax}\left\{M_{A}^{d} \sigma_{A}^{2} / E_{t} \pi_{A, t+1}, M_{B}^{d} \sigma_{B}^{2} / E_{t} \pi_{B, t+1}\right\},
$$

the speculators' hedge fund in our model engages in simple currency carry trades. In other words, in this case, currency $L$ is also the currency with the lower interest rate. Note that the fact that the two strategies are not equal implies that sometimes the speculators' optimal strategy is to borrow in the high interest rate (but low Sharpe ratio) currency and invest in the low interest rate (but high Sharpe ratio) currency. In this case the speculators invest in the high Sharpe ratio currency, borrowing at the real risk-free rate, and use the short position in the low Sharpe ratio currency to hedge their investment.

The possible difference in the real interest rates that may occur in equilibrium due to variations in inflation risks and partial market integration leads to the failure of the uncovered interest rate parity. Denoting by $R_{i, t}$ the period $t$ nominal interest rate in country $i$, noting that the rate of inflation in country $i$ equals $\pi_{i, t} / E_{t} \pi_{i, t+1}-1$, the uncovered interest rate parity is violated in equilibrium whenever

$$
\begin{aligned}
& \left(1+R_{i, t}\right) \neq\left(1+R_{j, t}\right) \frac{E_{t}\left(S_{t+1}^{i / j}\right)}{S_{t}^{i / j}} \\
& \Leftrightarrow \\
& \left(1+r_{i, t}\right) \frac{\pi_{i, t}}{E_{t} \pi_{i, t+1}} \neq\left(1+r_{j, t}\right) \frac{\pi_{j, t}}{E_{t} \pi_{j, t+1}} \frac{E_{t} \pi_{j, t+1} / E_{t} \pi_{i, t+1}}{\pi_{j, t} / \pi_{i, t}} \\
& \Leftrightarrow \\
& r_{i, t} \neq r_{j, t} .
\end{aligned}
$$

In our model, this occurs whenever investors are risk-averse and $M_{A}^{d} \sigma_{A}^{2} / E_{t} \pi_{A, t+1} \neq M_{B}^{d} \sigma_{B}^{2} / E_{t} \pi_{B, t+1}$. The failure of the uncovered interest rate parity (UIP), when it occurs, is an equilibrium phenomenon. Under the assumption that Eq. (17) holds, the failure of UIP is larger, i.e., the ratio of the right- and 
left-hand sides of (18) is further away from one when financial markets are segmented than when they are integrated. ${ }^{13}$

\section{The data}

We use a panel data set with data related to 11 main currencies spanning the time period from January 1979 to December $2008 .^{14}$ The data are on a monthly frequency and contain 3,120 currency-month observations. The selection of sample currencies and time period is driven by the availability of reliable data. Although ours is not a complete sample, we cannot think of any favorable systematic bias arising from the fact that not all possible currencies at all times have been included in our data set. ${ }^{15}$

Testing the predictions of the model requires data on interest rates, exchange rates, inflation risks, per capita money supplies, and hedge fund flows, which we use as a proxy for the change in the number of speculators. First, we obtain end-of-month interbank spot and one-month forward exchange rates as well as one-month interbank interest rates from Datastream. To find a proxy for the time-varying inflation risk, $h_{t}$, denoting by $e_{t}$ the period $t$ inflation shock, we estimate the following $\mathrm{AR}(1)-\mathrm{GARCH}(1,1)$ model for the rate of inflation, $d_{t}$ :

$$
\begin{aligned}
& d_{t}=\beta_{0}+\beta_{1} d_{t-1}+e_{t}, \quad e_{t} \sim N\left(0, h_{t}^{2}\right) \\
& h_{t}^{2}=\gamma_{0}+\gamma_{1} h_{t-1}^{2}+\gamma_{2} e_{t-1}^{2} .
\end{aligned}
$$

\footnotetext{
${ }^{13}$ Note that as investors become less risk averse, so that $a \rightarrow 0$, the interest rates in both countries approach the risk-free rate, given (6), and hence, the UIP will hold in the limit.

${ }^{14}$ The sample currencies are the main currencies of the Euro area (Belgium, France, Germany, Italy, and the Netherlands), Canada, Japan, Switzerland, the United Kingdom, and the United States. Data for the Euro legacy currencies end in December 1998 and data for the Euro area begin in January 1999. Our sample currencies are the same as those used by Burnside, Eichenbaum, Kleshchelski, and Rebelo (2006).

${ }^{15}$ On the contrary, we believe that these countries provide for conservative tests of our hypotheses. Our sample consists of major industrial countries with developed financial markets and broadly comparable monetary policy. We believe that finding evidence of capital restrictions and their effect on financial markets in this set of countries is more revealing than in a broader set of countries including those with less-developed financial markets.
} 
The model is estimated individually for each country using Organisation for Economic Cooperation and Development (OECD) data on the monthly rate of year-over-year inflation. We use the mean equation for $d_{t}$ as inflation forecasts and the time-varying variance term, $h_{t}^{2}$ as our proxy for the inflation risk. This approach is similar to those used by Grier and Perry (1998) and Hwang (2001), among others.

Our proxy for per capita money supply is M2 divided by the respective country's stock market capitalization. As the stock market capitalization reflects the size of the financial markets, we believe this ratio captures well a given country's citizens' ability to bear the inflation risk related to its monetary assets, thus capturing the intuition of the model. ${ }^{16}$ The data on M2 are from International Monetary Fund (IMF), National Bank of Belgium, Bank of England, and Mitchell (1992). These data are on a monthly frequency. In the few cases where monthly observations were not available, we calculated monthly estimates assuming that the growth of M2 between annual observations was constant. Stock market capitalizations are from Datastream and World Federation of Exchanges. ${ }^{17}$

Our proxy for the proportion of speculators is the hedge fund industry's total assets under management (AUM) divided by the total M2 money supply of the sample countries. The procedure for estimating the hedge fund industry's AUM is described in Appendix B. Fig. 1 shows the historical development of the hedge fund AUM divided by the total M2 money supply. The total hedge fund AUM grew from just over $0.2 \%$ of the total M2 in 1976 to over $6 \%$ in 2007 . The development of the AUM occurs in cycles, where periods of rapid growth are followed by sharp

\footnotetext{
${ }^{16}$ Second, in a more general model, such as Fama and Farber (1979), the market portfolios include the equity markets. In such a model, the relative sizes of the money supply and the equity market affect the covariance of inflation risk with the market portfolio, which in turn affects the equilibrium risk premium in nominal fixed income assets and the equilibrium interest rate in any given country.

${ }^{17}$ We use M2 instead of M3, for example, as this is available for all countries during our sample period.
} 
falls. The last two sharp falls in the AUM were triggered by the Long-Term Capital Management (LTCM) hedge fund crisis in 1998 and the 2008 global financial crisis.

[Insert Fig. 1 here]

We use the net flow of the new assets to hedge funds as our proxy for the change in the number of speculators. Flow is calculated as the difference between the change in the funds' AUM and the funds' monthly dollar returns. As before, we normalize the figures by dividing them by M2. ${ }^{18}$ We use the flow, rather than change in AUM, because of endogeneity problems related to the latter. We believe that using the asset flows is free of endogeneity problems as hedge funds typically require a notification period of up to several months prior to subscriptions and redemptions. The procedure for estimating flows is described in Appendix B. Panel A of Table 1 provides the basic summary statistics of the key variables and rates of changes of the variables.

[Insert Table 1 here]

\section{Do hedge funds engage in currency speculation?}

Our model predicts that in sufficiently non-integrated markets, speculators set up a hedge fund that borrows in currencies with low Sharpe ratios and invests in currencies with high Sharpe ratios. We refer to this strategy as the "risk-adjusted carry trade" strategy. When (17) holds, this strategy corresponds to the simple currency carry trade strategy, where investors borrow in low interest rate currencies and invest in high interest rate currencies. In this paper, we report the results based on both strategies. We do so because the results related to simple carry trade investments are

\footnotetext{
${ }^{18}$ The normalization is done either using the aggregate M2 of our sample currencies or, in the case of panel regressions, using individual countries' M2. The latter approach can be justified by noting that hedge fund flows are likely to have an amplified effect on interest rates and exchange rates of small currencies.
} 
of interest on their own, as this particular investment strategy is popular and has been widely discussed in the literature. The results are quantitatively and qualitatively similar for the two investment strategies, as the returns and portfolio compositions of the two strategies are highly correlated.

We consider the following investment strategies. At the end of each month, we rank the currencies according to their interest rates or estimated Sharpe ratios, which is defined as the nominal interest rate minus the expected inflation divided by the standard deviation of unexpected inflation. We borrow funds in the currencies that rank in the bottom third and invest in the top-third currencies. At the end of the next month, a new ranking is composed and new positions are entered into, accordingly. The borrowing and investing in currencies is executed through short and long positions in one-month currency forwards against the British pound. ${ }^{19}$ When analyzing the effects of currency speculation in the subsequent sections of this paper, we assume that all traders follow these particular strategies. ${ }^{20}$

Our first prediction is that the expected returns to this type of currency speculation are positive. Panel A of Table 1 presents the descriptive statistics for the monthly gross returns from our two investment strategies, and Fig. 2 shows the cumulative return, in British pounds, to a constant $£ 100$-size investment in the two long-short portfolios.

\section{[Insert Fig. 2 here]}

\footnotetext{
${ }^{19}$ The choice of numeraire is inconsequential as the resulting short and long positions in the numeraire currency cancel out.

${ }^{20}$ Our simple carry trade strategy differs somewhat from that used by Burnside, Eichenbaum, Kleshchelski, and Rebelo (2006) and Burnside, Eichenbaum, and Rebelo (2007) who take a long position in all the currencies that have a higher interest rate than the British pound and take a short position in all the currencies that have a lower interest rate than the British pound. Our approach of leaving out middle-ranking currencies matches that commonly used in the asset pricing literature and is similar to that used for currencies by Lustig and Verdelhan (2007) and Lustig, Roussanov, and Verdelhan (2008).
} 
The mean monthly return from the simple carry trade strategy is $0.47 \%$, which corresponds to a $5.63 \%$ annual return. The standard deviation of the monthly returns is $2.06 \%$, resulting in a monthly Sharpe ratio of 0.228 (0.789 annualized). The results for the risk-adjusted carry trade strategy are similar, with somewhat lower mean and higher standard deviation. The monthly Sharpe ratio of this strategy is $0.159 .^{21,22}$

Panel B of Table 1 presents the means of the key variables and their changes when a currency belongs to the lowest-third ("short") or the highest-third ("long") based on our rankings of the sample currencies. Note that the real interest rates (nominal interest rate minus expected inflation) are higher for the long than the short currencies. Note also that the long currencies have higher per capita money supply when compared to the short currencies. This corresponds to our intuition that speculators should borrow from capital rich countries, such as Switzerland, Germany, or Japan, where M2 per stock market capitalization (or M2 per investor) is small, and invest the proceeds in less wealthy economies.

Our second prediction is that hedge funds should invest in these types of currency carry trading strategies. Table 2 presents the correlation between returns from our two currency trading strategies and select Credit Suisse/Tremont Hedge Fund indexes.

[Insert Table 2 here]

${ }^{21}$ Since these are zero-investment strategies, Sharpe ratio is simply the average of returns divided by the standard deviation of returns.

${ }^{22}$ To allow for some comparison, over the same time period, the US stock market had an average monthly return of $0.96 \%$, monthly standard deviation of $4.51 \%$, and monthly Sharpe ratio of 0.109 (0.376 annualized). Our results, related to simple carry trades, are in line with those by Burnside, Eichenbaum, Kleshchelski, and Rebelo (2006), allowing for the fact that their method of constructing portfolios slightly differs from ours. 
The returns from our strategies are highly correlated with the returns from various hedge fund indexes, indicating that hedge funds do, indeed, apply similar strategies to those that we have identified. Both of our strategies' returns are highly correlated with the overall hedge fund index returns as well as with the returns to fixed income arbitrage, global macro, and multi-strategy sub-indexes. Incredibly, the risk-adjusted carry trade strategy explains $16 \%$ of the overall hedge fund index returns and $33 \%$ of the fixed income arbitrage sub-index returns. ${ }^{23}$

To test if the returns to our currency trading strategies are significant in the presence of other risk factors, we regress the hedge fund index returns on a number of previously used risk factors as well as the returns from our two carry trade strategies. More precisely, we extend the seven hedge fund risk-factor model of Fung and Hsieh (2004) by adding the returns to our trading strategies as the eighth factor. ${ }^{24}$ The results of regressing the returns of the broad hedge fund index as well as global macro, fixed income arbitrage, and multi-strategy indexes on the seven and eight factors are reported in Table 3.

[Insert Table 3 here]

All four hedge fund indexes presented have a statistically significant exposure to the currency carry trade factors, even in the presence of the other seven factors. The currency carry trade factors appear to be especially important for the global macro funds. The inclusion of the simple carry trade factor increases the model's power to explain variation in global macro funds'

\footnotetext{
${ }^{23}$ Some additional evidence related to hedge funds' exposure to individual currency carry trade pairs is presented in McGuire and Upper (2007). Our results related to simple carry trades are similar to those in Lyytinen (2007), who shows a positive correlation between currency carry trade and hedge fund returns, and Pojarliev and Levich (2008a, 2008b) who show that currency hedge fund returns are highly correlated with an index of carry trade returns.

${ }^{24}$ The seven factors used by Fung and Hsieh (2004) are three trend-following factors (for bonds, currencies, and commodities; Fung and Hsieh, 2001), an equity market factor (Standard \& Poor's 500), a size spread factor (Russell 2000 minus Standard \& Poor's 500), a bond market factor (monthly change in the ten-year treasury constant maturity yield), and a credit spread factor (monthly change in the Moody's Baa yield minus ten-year treasury constant maturity yield). Data for the trend-following factors are available on David Hsieh's Web site: http://faculty.fuqua.duke.edu/ dah7/DataLibrary/TF-FAC.xls.
} 
returns, measured by $R$-squared, from $19 \%$ to $28 \%$. These findings suggest that hedge funds in general, and global macro and fixed income arbitrage funds in particular, engage in currency speculation using carry trades.

\section{Hedge fund flows and returns to carry trades}

Proposition 2 predicts that as barriers to international currency investments become smaller, new investors invest into hedge funds that engage in currency speculation. As the number of hedge fund investors increases, as the funds' investments affect market prices, the expected returns from the currency speculation strategies applied by hedge funds decrease. The fitted polynomial trends to the cumulative returns from the two carry trade strategies, shown in Fig. 2, suggest that the returns from our strategies have indeed been decreasing over time, as the volume of assets under management in hedge funds has grown. To show this change in the profitability in another way, we divide our sample period into three sub periods based on the total hedge fund assets under management and present the returns and the Sharpe ratios for the two strategies in each of the time periods in Fig. 3.

[Insert Fig. 3 here]

During the first period, when hedge fund AUM is below USD 100 billion, the average monthly return to simple carry trade is $0.69 \%$ ( $0.51 \%$ for the risk-adjusted carry trade $)$ whereas it is only $0.17 \%(0.17 \%)$ during the last period when hedge fund AUM is over USD 500 billion. Further, the monthly Sharpe ratio of the simple (risk-adjusted) carry trade strategy decreases from 0.37 (0.27) in the first period to only $0.09(0.09)$ in the last period. 
To study further the relation between the number of speculators and the currency carry trade returns, we regress the returns from the two trading strategies on the previous month's hedge fund AUM and the current month's hedge fund flow and report the results in Table 4.

[Insert Table 4 here]

The hedge fund AUM has a negative and statistically significant effect on the returns to the simple carry trade strategy, whereas the current month's hedge fund flow has a significant positive effect. These results, consistent with Proposition 2, hold for both raw returns (column 1) and Fama and French (1993) three-factor risk-adjusted returns (column 2). The results also exhibit economic significance. For instance, according to our estimates for the last five years of the sample period (2004-2008), a one-standard deviation increase in hedge fund flows results in a $0.08 \%$ increase in the simple carry trade returns, which corresponds to about $40 \%$ of this strategy's returns' standard deviation during the same period. The results related to the risk-adjusted carry trades are of the predicted direction, but their statistical significance is weak.

\section{Hedge fund flows and interest rates}

Proposition 2 predicts that an increase in the number of speculators will decrease (increase) the interest rate in the high (low) per capita inflation risk countries. To test this prediction, we regress the changes in the interest rates on hedge fund flows and changes in other determinants of interest rates in our model, namely forecast inflation, inflation risk, and M2 per stock market capitalization. The inflation forecasts are calculated as one-step-ahead forecasts from the inflation model presented in Eq. (19). Since the changes in interest rates exhibit strong negative autocorrelation, we also include the lagged interest rate change as an explanatory variable. 
As we expect the hedge fund flows (corresponding to changes in the number of speculators) to have opposite effects on interest rates in high and low Sharpe ratio countries, or, assuming (17) holds, on high and low interest rates, we include an indicator variable in the regression to indicate whether the country belongs to a currency speculators' short or long portfolio and interact this indicator variable with the hedge fund flows. The indicator variable, Position, equals minus one for countries that belong to the lowest one-third in the Sharpe ratio, or interest rate, ranking, plus one for countries that belong to the highest one-third, and zero for the rest. Results of regressing the changes in interest rates on changes in inflation forecast, inflation risk, money supplies, and the Position times the hedge fund flows are presented in Table 5. The Position variable is based on the Sharpe ratio rankings in column 1 and on the interest rate rankings in column 2 .

[Insert Table 5 here]

Changes in interest rates are positively and statistically significantly related to changes in both inflation risk and money supply, providing empirical support for the baseline model. The finding that inflation risk is a significant determinant of interest rates is in line with studies such as Shen (1998) and Buraschi and Jiltsov (2005) that show positive and significant inflation risk premiums in nominal interest rates.

The hedge fund flows have a significant effect on interest rates in the direction predicted by the theoretical model: positive flow decreases (increases) the interest rates in high (low) Sharpe ratio, or interest rate, countries. Over the last five years of the sample period (20042008), the time-series standard deviation of hedge fund flows per M2 was about $2 \%$. Hence, a onestandard deviation increase in hedge fund flows would result, on average, in a $0.07 \%$ decrease 
(increase) in interest rates in the high (low) Sharpe ratio currencies. Such a change corresponds to about $29 \%$ of the standard deviation of interest rate changes over the same period, which is economically significant. ${ }^{25}$

Proposition 2 further predicts that the Sharpe ratios of the fixed income assets in highand low-interest rate countries should converge over time as the number of speculators increases. Such convergence is evident in Fig. 4, which shows the average Sharpe ratios for the long and short currencies in the two strategies. $^{26}$

[Insert Fig. 4 here]

\section{Hedge fund flows and exchange rates}

A final prediction of the model is that hedge fund flows (corresponding to changes in the number of speculators) affect exchange rates. The prediction is that inflows (outflows) to hedge funds will lead to an appreciation (depreciation) of high (low) Sharpe ratio or, assuming (17) holds, high (low) interest rate currencies. We examine this effect by regressing the changes in spot exchange rates on hedge fund flows, and forward premium, and present the results in Table 6. As we expect the hedge fund flows to have opposite effects on high and low Sharpe ratio (or interest rate) currencies, we interact the hedge fund flows with the Position variables described in Section 7. The Position variable is based on the Sharpe ratio rankings in column 1 and on the interest rate rankings in column 2. The spot exchange rate change is calculated for each currency against a

\footnotetext{
${ }^{25}$ Similarly, a one-standard deviation increase in hedge fund flows would result, on average, in a $0.06 \%$ decrease (increase) in interest rates in the high (low) interest rate currencies which corresponds to $23 \%$ of the standard deviation of interest rate changes.

${ }^{26}$ In addition, it seems that the Sharpe ratios for fixed income investments in general have fallen over time, possibly reflecting better risk sharing in integrated markets.
} 
basket containing all the other currencies in the sample. In this way, we mitigate problems arising from using a single currency as a numeraire.

\section{[Insert Table 6 here]}

The effect of hedge fund flows on spot exchange rates is significantly positive. During months of positive flows, high Sharpe ratio (or high interest rate) currencies appreciate and low Sharpe ratio (or low interest rate) currencies depreciate. Based on estimates from the last five years of the sample period (2004-2008), a one-standard deviation increase in hedge fund flows would, on average, result in a $0.09 \%$ appreciation (depreciation) in the exchange rate of the high (low) Sharpe ratio currencies. Such a change corresponds to about $4 \%$ of the standard deviation of exchange rate changes over the same period, which is economically significant. ${ }^{27}$

The results above are in line with those of Evans and Lyons (2002) who find, using daily data, that deal flow explains a large part of variation in exchange rates. The difference is that we are able to trace the origin of some of the deal flow to hedge funds engaged in currency speculation. A similar prediction to ours - that carry trades affect exchange rates - is present in Plantin and Shin (2010) and Brunnermeier, Nagel and Pedersen (2009).

During the latter half of 2008, hedge funds experienced a dramatic outflow of capital, with the total industry AUM falling from almost USD 2 trillion by the end of June to USD 1.4 trillion by the end of the year. During this time period, the hedge fund redemptions totaled $17.5 \%$ of AUM which corresponds to 4.3 times the standard deviation of the semi-annual flows. At the same time, consistent with Proposition 2, high Sharpe ratio (high interest rate) currencies depreciated

\footnotetext{
${ }^{27}$ Similarly, a one-standard deviation increase in flows would, on average, result in a $0.19 \%$ appreciation (depreciation) in the exchange rate of the high (low) interest rate currencies, which corresponds to about $8 \%$ of the standard deviation of exchange rate changes.
} 
significantly while low Sharpe ratio (low interest rate) currencies appreciated. On average, the carry trade short currencies based on the Sharpe ratio (interest rate) rankings appreciated by $6.2 \%$ $(15.4 \%)$ while the carry trade long currencies depreciated by $10.9(11 \%)$ relative to baskets of all other currencies. The magnitude of these currency changes is, on average, 2.2 (3.6) times the standard deviation of the semi-annual exchange rate changes. Based on the estimates in Table 6, hedge fund flows can account for $26 \%(22 \%)$ of the average appreciation of the low Sharpe ratio (interest rate) currencies and 7\% (11\%) of the average depreciation of high Sharpe ratio (interest rate) currencies during this time period. According to our estimates, therefore, in the fall of 2008, the carry trade long currencies depreciated by roughly $2.3-4.6 \%$ against the carry trade short currencies due to hedge fund flows, providing additional evidence of the economic significance of the effect of hedge fund flows on exchange rates. ${ }^{28}$

\section{Conclusion}

In this paper, we study a two-country general equilibrium model with partially segmented markets for nominal fixed income securities. In sufficiently segmented markets, when inflation shocks are highly correlated, all unrestricted investors invest in a leveraged hedge fund that borrows from the country with the lower Sharpe ratio for fixed income securities while investing in the country with the higher Sharpe ratio. Under certain assumptions, this strategy coincides with the simple carry trade strategy, where investment decisions are based on interest rate as opposed to Sharpe ratio rankings. In our model, hedge funds play a positive economic role,

${ }^{28}$ There are at least two reasons, however, why the extreme exchange rate changes in the fall of 2008 may be even to a greater extent due to the unwinding of the hedge funds' carry trade positions. First, one should recognize that the large hedge fund outflows in the fall of 2008 occurred at the time of a global credit crisis. Given this, the hedge funds have most likely unwound their positions in 2008 not only due to the outflow of money from the funds, but also in an effort to decrease in their leverage ratios, as during this time period the availability of funding credit became very tight. This is, in fact, what Brunnermeier, Nagel, and Pedersen (2009) argue is the case. Second, as predicted by Brunnermeier and Pedersen (2009), it is likely that during the credit crises the liquidity in all markets, including the currency market, was exceptionally low. This implies that at that time the unwinding of the hedge funds' carry trade positions probably had a much greater effect on exchange rates, as compared to normal times, as in the fall of 2008 also all the other market participants, who normally provide liquidity to the market, were highly constrained. 
transferring money from a country with little domestic inflation risk to a country with higher inflation risk, leading to better international risk sharing and an increase in the utilities of all agents. When the costs for making international financial transactions decrease, more investors invest in the hedge fund, whose investments affect market interest rates, the exchange rate, and both the hedge fund's contemporaneous and expected future returns.

Empirically, we show that a long-short investment strategy that is based on the rankings of currencies by their estimated Sharpe ratios (or interest rates) can explain a large fraction of various hedge fund index returns, implying that hedge funds do engage in this type of currency speculation. Our evidence suggests that the hedge fund industry is also large enough, so that the hedge funds' investments have affected market prices in the fixed income and currency markets. Our estimate of the total hedge fund industry's assets under management was, in recent years, close to $6 \%$ of the M2 money supply of our sample currencies, which include the currencies of the largest industrialized countries in the world. When assessing the magnitude of this amount, recognizing that hedge funds pursue many different strategies in addition to those that we have identified, one must also recognize that the hedge fund investments are typically highly leveraged, amplifying the amount of money that may have been invested in such trades. ${ }^{29}$ Given the huge volume of leveraged assets under management, it is hardly surprising that the flow of hedge fund assets under management has had a statistically significant price effect in the fixed income and currency markets.

Our results also shed some light on the forward premium puzzle, which has attracted much attention in academia. In our model, the uncovered interest rate parity does not typically hold in equilibrium, as real interest rates differ across countries due to variations in inflation risks and

${ }^{29}$ In the past, leverage ratios of up to 12:1 have been estimated for some types of hedge funds (see McGuire, Remolona, and Tsatsaronis, 2005). 
money supplies. Furthermore, under certain assumptions which, according to our estimates are typically satisfied, the failure of the uncovered interest rate parity is larger in segmented financial markets as opposed to an integrated financial market. Under the same assumptions, the process of market integration leads to additional hedge fund investments into high real interest rate currencies, which in turn leads to the appreciation of those currencies, and to short selling and the subsequent depreciation of the low interest rate currencies. Consequently, according to our results, it is likely that the market integration during the past few decades has biased upwards the empirical estimates of the failure of the uncovered interest rate parity. 


\section{Appendix A. Proofs}

Proof of Proposition 1. The claim that the hedge fund's expected returns are positive follows from the fact that zero positions are also feasible. The proof of all other claims follows directly from Eqn. (9) and the first partial derivative of (9) with respect to $k_{i}$ and $k_{j}$, and are omitted.

Proof of Proposition 2. First, using (5), (8) and (10) we obtain:

$$
b_{i}^{s^{*}}=\frac{b_{i}^{d^{*}}-\left(\frac{b_{j}^{d^{*}} \sigma_{j} \rho}{\sigma_{i}}\right)}{\left(1-\rho^{2}\right)} .
$$

Here, we have made use of the result, implied by (5) and (10), that $E_{t} \tilde{\pi}_{i, t+1}{ }^{*} p_{i, t}^{*}\left(1+r_{f}\right)=a b_{i}^{d^{*}} \sigma_{i}^{2}$, in equilibrium. Now, using (20), let us first show that the speculators' fund's equilibrium profits,

$$
\begin{aligned}
& V^{s^{*}}=b_{L}^{s^{*}}\left(E_{t} \tilde{\pi}_{L, t+1^{-}} p_{L, t}^{*}\left(1+r_{f}\right)\right)+b_{H}^{s^{*}}\left(E_{t} \tilde{\pi}_{H, t+1^{-}} p_{H, t}^{*}\left(1+r_{f}\right)\right)= \\
& b_{L}^{s^{*}} b_{L}^{d^{*}} a \sigma_{L}^{2}+b_{H}^{s^{*}} b_{H}^{d^{*}} a \sigma_{H}^{2}=\frac{b_{L}^{d^{* 2}} a \sigma_{L}^{2} b_{H}^{d^{*}} a \sigma_{H}^{2}-2 b_{H}^{d^{*}} b_{L}^{d^{*}} a \sigma_{H} \sigma_{L} \rho}{\left(1-\rho^{2}\right)},
\end{aligned}
$$

decrease as $k_{i}$ increases. Differentiating (21) with respect to $b_{L}^{d^{*}}$ and $b_{H}^{d^{*}}$, and using (10) to sign the derivatives, gives:

$$
\begin{aligned}
& \frac{\partial V^{S^{*}}}{\partial b_{H}^{d^{*}}}=2 a \sigma_{H} \frac{b_{H}^{d^{*}} \sigma_{H}-b_{L}^{d^{*}} \sigma_{L} \rho}{\left(1-\rho^{2}\right)}>0 \\
& \frac{\partial V^{S^{*}}}{\partial b_{L}^{d^{*}}}=2 a \sigma_{L} \frac{b_{L}^{d^{*}} \sigma_{L}-b_{H}^{d^{*}} \sigma_{H} \rho}{\left(1-\rho^{2}\right)}<0
\end{aligned}
$$


when $k_{L}<\bar{k}_{L}$. This provides the result as $\frac{\partial b_{L}^{d^{*}}}{\partial k_{i}}>0$ and $\frac{\partial b_{H}^{d^{*}}}{\partial k_{i}}<0$, where $i \in\{L, H\}$, given (10), for the range of parameters considered. These last two partial derivatives also prove our claim that the Sharpe ratios converge, as the number of speculators increases, as given (7) and (23), we have

$$
S R_{L}^{*}=a b_{L}^{d^{*}} \sigma_{L}<a b_{H}^{d^{*}} \sigma_{H} \rho<a b_{H}^{d^{*}} \sigma_{H}=S R_{H}^{*}
$$

This result also implies, given (13), that all the speculators, when $k_{L}<\bar{k}_{L}$, come from country $L$.

We now prove that a decrease in $\phi$ leads to an increase in the number of speculators. In equilibrium, the utilities of the two types of investors must be equal. Following a decrease in $\phi$, other things equal, the speculators' utility is higher than that for the domestic investors, prompting more domestic investors to turn into speculators. As we show below, an increase in the number of speculators increases domestic investors' utility relative to the utility of the speculators. Entry of speculators continues until the utilities are again equal.

Using (5) and (10), the ratio of the expected utilities, $u\left(\widetilde{c}_{t+1}\right)=-E_{t} e^{-a \widetilde{c}_{t+1}}$, where $\widetilde{c}_{t+1}$ is defined by (2), of the domestic investors and speculators from country $L$ can be written as:

$$
\begin{gathered}
\frac{u_{L}\left(\widetilde{c}_{t+1}^{d}\right)}{u_{L}\left(\widetilde{c}_{t+1}^{s}\right)}=\frac{-e^{-a\left(E_{t} \widetilde{c}_{L, t+1}^{d^{*}} \frac{a}{2} b_{L}^{d^{* 2}} \sigma_{L}^{2}\right)}}{-e^{-a\left(E_{t} \widetilde{c}_{L, t+1}^{s^{*}} \frac{a}{2} b_{L}^{s^{* 2}} \sigma_{L}^{2}-\frac{a}{2} b_{H}^{s^{* 2}} \sigma_{H}^{2}-a b_{L}^{s^{*}} b_{H}^{s^{*}} \rho \sigma_{L} \sigma_{H}\right)}} \\
=e^{-a\left(\frac{a}{2} b_{L}^{d^{* 2}} \sigma_{L}^{2}\right)+a\left(a b_{L}^{s^{*}} b_{L}^{d^{*}} \sigma_{L}^{2}+a b_{H}^{s^{*}} b_{H}^{d^{*}} \sigma_{H}^{2}-\frac{a}{2} b_{L}^{s^{* 2}} \sigma_{L}^{2}-\frac{a}{2} b_{H}^{s^{* 2}} \sigma_{H}^{2}-a b_{L}^{s^{*}} b_{H}^{s^{*}} \rho \sigma_{L} \sigma_{H}-\phi(1+r)\right)},
\end{gathered}
$$


where we have made use of the fact that the first-order condition of (2) with respect to $m_{i, t}$ implies that the domestic investors and speculators select equal money holdings in equilibrium.

As $\phi$ decreases, (25) increases. When $k_{L}<\bar{k}_{L},(10)$ implies that the first term in the exponential of (25), in equilibrium, $-\frac{\mathrm{a}^{2}}{2} b_{L}^{d^{2}} \sigma_{L}^{2}$, is decreasing in the number of speculators. We now want to show that the second term in the exponential is also decreasing in the number of speculators.

Differentiating this term with respect to $b_{H}^{d^{*}}$ and $b_{L}^{d^{*}}$ gives:

$$
\begin{aligned}
& \frac{\partial a\left(\mathrm{a} b_{L}^{s^{*}} b_{L}^{d^{*}} \sigma_{L}^{2}+a b_{H}^{s^{*}} b_{H}^{d^{*}} \sigma_{H}^{2}-\frac{\mathrm{a}}{2} b_{L}^{s^{* 2}} \sigma_{L}^{2}-\frac{\mathrm{a}}{2} b_{H}^{s^{* 2}} \sigma_{H}^{2}-a b_{L}^{s^{*}} b_{H}^{s^{*}} \rho \sigma_{L} \sigma_{H}-\phi(1+r)\right)}{\partial b_{H}^{d^{*}}} \\
= & a \frac{\partial V^{s^{*}}}{\partial b_{H}^{d^{*}}}-a^{2} b_{L}^{s^{*}} \sigma_{L}^{2} \frac{\partial b_{L}^{s^{*}}}{\partial b_{H}^{d^{*}}}-a^{2} b_{H}^{s^{*}} \sigma_{H}^{2} \frac{\partial b_{H}^{s^{*}}}{\partial b_{H}^{d^{*}}}-a^{2} b_{H}^{s^{*}} \rho \sigma_{L} \sigma_{H} \frac{\partial b_{L}^{s^{*}}}{\partial b_{H}^{d^{*}}}-a^{2} b_{L}^{s^{*}} \rho \sigma_{L} \sigma_{H} \frac{\partial b_{H}^{s^{*}}}{\partial b_{H}^{d^{*}}} \\
= & a^{2} \sigma_{H} \frac{2 b_{H}^{d^{*}} \sigma_{H}-2 b_{L}^{d^{*}} \sigma_{L} \rho}{\left(1-\rho^{2}\right)}-a^{2} b_{H}^{s^{*}} \sigma_{H}^{2}>a^{2} \sigma_{H}\left(\frac{2 b_{H}^{d^{*}} \sigma_{H}-2 b_{L}^{d^{*}} \sigma_{L} \rho-b_{H}^{d^{*}} \sigma_{H}+b_{L}^{d^{*}} \sigma_{L} \rho}{\left(1-\rho^{2}\right)}\right) \\
= & a^{2} \sigma_{H}\left(\frac{b_{H}^{d^{*}} \sigma_{H}-b_{L}^{d^{*}} \sigma_{L} \rho}{\left(1-\rho^{2}\right)}\right)>0
\end{aligned}
$$

by (22). Similarly by (23),

$$
\frac{\partial a\left(\mathrm{a} b_{L}^{s^{*}} b_{L}^{d^{*}} \sigma_{L}^{2}+a b_{H}^{s^{*}} b_{H}^{d^{*}} \sigma_{H}^{2}-\frac{\mathrm{a}}{2} b_{L}^{s^{* 2}} \sigma_{L}^{2}-\frac{\mathrm{a}}{2} b_{H}^{s^{2}} \sigma_{H}^{2}-a b_{L}^{s^{*}} b_{H}^{s^{*}} \rho \sigma_{L} \sigma_{H}-\phi(1+r)\right)}{\partial b_{L}^{d^{*}}}=
$$




$$
\begin{aligned}
& =a^{2} \sigma_{L} \frac{2 b_{L}^{d^{*}} \sigma_{L}-2 b_{H}^{d^{*}} \sigma_{H} \rho}{\left(1-\rho^{2}\right)}-a^{2} b_{L}^{s^{*}} \sigma_{L}^{2}<a^{2} \sigma_{L}\left(\frac{2 b_{L}^{d^{*}} \sigma_{L}-2 b_{H}^{d^{*}} \sigma_{H} \rho-b_{L}^{d^{*}} \sigma_{L}+b_{H}^{d^{*}} \sigma_{H} \rho}{\left(1-\rho^{2}\right)}\right) \\
& a^{2} \sigma_{L}\left(\frac{b_{L}^{d^{*}} \sigma_{L}-b_{H}^{d^{*}} \sigma_{H} \rho}{\left(1-\rho^{2}\right)}\right)<0 .
\end{aligned}
$$

This proves the result as $\frac{\partial b_{L}^{d^{*}}}{\partial k_{L}}>0$ and $\frac{\partial b_{H}^{d^{*}}}{\partial k_{L}}<0$ given (10), for the range of parameters considered.

The remaining results regarding the interest rates, bond prices, and the contemporaneous profits to the hedge fund follow from (5), (6), and the derivative of (10) with respect to $k_{i}$ and $k_{j}$. 


\section{Appendix B. Estimation procedures}

It is quite difficult to obtain reliable monthly estimates for the hedge fund industry's AUM dating back in time. First, Hedge Fund Research, Inc. (HFR) provides annual estimates of the hedge fund industry's total AUM from 1990 onwards. Second, we find some evidence on the size of the markets for the earlier period from Hennessee Group LLC, but it is only for the years 1974 and 1987. In addition, we use the Lipper TASS database, which provides monthly observations on individual funds dating back to 1977 , and covers a large (currently $80 \%$ ) but varying proportion of the total hedge fund industry.

To form a monthly series of the hedge fund AUM, we start with the annual estimates of the total hedge fund AUM by HFR and the two earlier estimates by Hennessee. Next, we calculate asset-weighted averages of returns and new asset flows to all the funds included in the Lipper TASS database for each month. As the year-to-year asset growth of the Lipper TASS funds does not match the growth in the hedge fund industry indicated by the estimates provided by HFR and Hennessee, due to the changing coverage in Lipper TASS, we make the assumption that each year the difference between the two growth figures accumulates steadily over the year. Hence, our estimated hedge fund AUM growth is the asset-weighted average growth in the AUM of the hedge funds reporting to the Lipper TASS database plus one-twelfth of the difference in the current year's asset growth estimates obtained from HFR or Hennessee and the Lipper TASS database. In this way, we get a monthly estimate of the hedge fund AUM whose end-of-year figure matches the estimates of HFR and Hennessee and whose monthly growth pattern resembles as closely as possible that of the population of funds reporting to the Lipper TASS database. ${ }^{30}$

\footnotetext{
${ }^{30}$ Some discussion on the difficulties of finding good proxies to measure carry trade activity can be found in Galati, Heath, and McGuire (2007).
} 
Our estimate of the hedge fund industry's asset flow is based on all funds in the Lipper TASS database and our AUM estimates. We calculate an estimate of percentage asset flow to each fund for each month, when reported asset and return figures are available, take an assetweighted average of these percentage flows, and multiply this by our estimate of the total hedge fund industry AUM to obtain an estimate of the flow in dollar terms. 


\section{References}

Albuquerque, R., 2008. The forward premium puzzle in a model of imperfect information: theory and evidence. Economic Letters 99, 461-464.

Alvarez, F., Atkenson, A., Kehoe, P., 2009. Time-varying risk, interest rates, and exchange rates in general equilibrium. Review of Economic Studies 76, 851-878.

Arellano M., 1987. Computing robust standard errors for within group estimators. Oxford bulletin of Economics and Statistics 49, 431-434.

Avramov, D., Barras, L., Kosowski, R., 2009. Hedge fund predictability under the magnifying glass: forecasting individual fund returns using multiple predictors. Unpublished working paper. University of Maryland, McGill University, and Imperial College.

Bacchetta, P., Van Wincoop, E., 2006. Can information heterogeneity explain the exchange rate determination puzzle? American Economic Review 96, 552-576.

Backus, D., Foresi, S., Telmer, C., 2001. Affine term structure models and the forward premium anomaly. Journal of Finance 56, 279-304.

Backus, D., Gregory, A., and Telmer, C., 1993. Accounting for forward rates in markets for foreign currency. Journal of Finance 48, 1887-1908.

Bansal, R., Dahlquist, M., 2000. The forward premium puzzle: different tales from developed and emerging economies. Journal of International Economics 51, 115-144.

Bansal, R., Shaliastovich, I., 2009. A long-run risks explanation of predictability puzzles in bond and currency markets. Unpublished working paper. Duke University.

Baquero, G., Verbeek, M., 2009. A portrait of hedge fund investors: flows, performance and smart money. Unpublished working paper. ESMT European School of Management and Technology, Erasmus University. 
Bekaert, G., 1996. The time variation of risk and return in foreign exchange markets: a general equilibrium perspective. Review of Financial Studies 9, 427-470.

Bekaert, G., Hodrick, R., Marshall, D., 1997. The implications of first-order risk aversion for asset market risk premiums. Journal of Monetary Economics 40, 3-39.

Bilson, J., 1981. The "speculative efficiency" hypothesis. The Journal of Business 54, 435-451.

Brunnermeier, M., Pedersen, L., 2009. Market liquidity and funding liquidity. Review of Financial Studies 22, 2201-2238.

Brunnermeier, M., Nagel, S., Pedersen, L., 2009. Carry trades and currency crashes. NBER Macroeconomics Annual 2008, 313-347.

Buraschi, A., Jiltsov, A., 2005. Inflation risk premia and the expectations hypothesis. Journal of Financial Economics 75, 429-490.

Burnside, C., Eichenbaum, M., Kleshchelski, I., Rebelo, S., 2006. The returns to currency speculation. NBER Working Paper No. W12489.

Burnside, C., Eichenbaum, M., Rebelo, S., 2007. The returns to currency speculation in emerging markets. American Economic Review 97, 333-338.

Burnside, C., Eichenbaum, M., Rebelo, S., 2009, Understanding the forward premium puzzle: a microstructure approach. American Economic Journal: Macroeconomics 1, 127-54.

Burnside C., Han, B., Hirshleifer, D., Wang, T., 2010. Investor Overconfidence and the Forward Discount Puzzle. NBER Working Paper No. W15866.

Campbell, J., Grossman, S., Wang, J., 1993. Trading volume and serial correlation in stock returns. Quarterly Journal of Economics 108, 905-939.

Cumby, R., 1988. Is it risk? Explaining deviations from uncovered interest parity. Journal of Monetary Economics 22, 279-299. 
DeLong, J., Shleifer, A., Summers, L., Waldmann, R., 1990. Noise trader risk in financial markets. Journal of Political Economy 98, 703-738.

Ding, B., Getmansky, M., Liang, B., Wermers, R., 2007. Hedge fund flows and contagion in financial markets. Unpublished working paper. University at Albany, University of Massachusetts Amherst, University of Maryland.

Einzig, P., 1961. A Dynamic Theory of Forward Exchange. Macmillan, London.

Engel, C., 1996. The forward discount anomaly and the risk premium: a survey of recent evidence. Journal of Empirical Finance 3, 123-192.

Evans, M., Lyons, R., 2002. Order flow and exchange rate dynamics. Journal of Political Economy $110,170-180$.

Fama, E., 1984. Forward and spot exchange rates. Journal of Monetary Economics 14, 319-338.

Fama, E., Farber, A., 1979. Money, bonds, and foreign exchange. American Economic Review 69, 639-649.

Fama, E., French, K., 1993. Common risk factors in the returns on stocks and bonds. Journal of Financial Economics 33, 3-56.

Farhi, E., Gabaix, X., 2008. Rare disasters and exchange rates. NBER Working Paper No. W13805.

Froot, K. Thaler, R., 1990. Anomalies: foreign exchange. Journal of Economic Perspectives 4, 179192.

Fung, W., Hsieh, D., 2000. Measuring the market impact of hedge funds. Journal of Empirical Finance 7, 1-36.

Fung, W., Hsieh, D., 2001. The risk in hedge fund strategies: theory and evidence from trend followers. Review of Financial Studies 14, 313-341. 
Fung, W., Hsieh, D., 2004. Hedge fund benchmarks: a risk based approach. Financial Analyst Journal 60, 65-80.

Galati, G., Heath, A., McGuire, P., 2007. Evidence of carry trade activity. BIS Quarterly Review, September 2007, 27-41.

Gârleanu, N., Pedersen, L., Poteshman, A., 2009. Demand-based option pricing. Review of Financial Studies 22, 4259-4299.

Gourinchas, P.-O., Tornell, A., 2004. Exchange rate puzzles and distorted beliefs. Journal of International Economics 64, 303-333.

Greenwood, R., Vayanos, D., 2008. Bond supply and excess bond returns. NBER Working Paper No. 13806.

Grier, K., Perry, M., 1998. On Inflation and inflation uncertainty in the G7 countries. Journal of International Money and Finance 17, 671-689.

Gromb, D., Vayanos, D., 2002. Equilibrium and welfare in markets with financially constrained arbitrageurs. Journal of Financial Economics 66, 361-407.

Grossman, S., 1995. Dynamic asset allocation and informational efficiency of markets. Journal of Finance 50, 773-789.

Grubel, H., 1965. Profits from forward exchange speculation. Quarterly Journal of Economics 79, $248-262$.

Hollifield, B., Uppal, R., 1997. An examination of uncovered interest rate parity in segmented international commodity markets. Journal of Finance 52, 2145-2170.

Hwang, Y., 2001. Relationship between inflation rate and inflation uncertainty. Economics Letters 73, 179-186.

Keynes, J., 1923, A Tract on Monetary Reform. Macmillan \& Co, London. 
Kyle, A., Xiong, W., 2001. Contagion as a wealth effect. Journal of Finance 56, 1401-1440.

Lustig, H., Roussanov, N., Verdelhan, A., 2008. Common risk factors in currency markets. NBER Working Paper No. 14082.

Lustig, H., Verdelhan, A., 2007. The cross-section of foreign currency risk premia and U.S. consumption growth risk. American Economic Review 97, 89-117.

Lyons, R., 2001. The Microstructure Approach to Exchange Rates. MIT Press, Cambridge, MA.

Lyytinen, J.-P., 2007. Currency carry trades - betting against the uncovered interest parity. Master's Thesis supervised by Matti Suominen. Helsinki School of Economics.

Mark, N., Wu, Y., 1998. Rethinking deviations from uncovered interest parity: the role of covariance risk and noise. The Economic Journal 108, 1686-1706.

McGuire, P., Remolona E., Tsatsaronis, K., 2005. Time-varying exposures and leverage in hedge funds. BIS Quarterly Review, March 2005, 59-72.

McGuire, P., Upper, C., 2007. Detecting FX carry trades. BIS Quarterly Review, March 2007, 8-9.

Mitchell, B., 1992. International Historical Statistics: Europe 1750-1988. Stockton Press, New York.

Newey, W., West, K., 1987. A simple, positive semi-definite, heteroskedasticity and autocorrelation consistent covariance matrix. Econometrica 55, 703-708.

Plantin, G., Shin, H., 2010. Carry trades and speculative dynamics. Unpublished working paper. Toulouse School of Economics, Princeton University.

Pojarliev, M., Levich, R., 2008a. Do professional currency managers beat the benchmark? Financial Analysts Journal 65, 18-32.

Pojarliev, M., Levich, R., 2008b. Trades of the living dead: style differences, style persistence and performance of currency fund managers? NBER Working Paper No. W14355. 
Prachowny, M., 1970. A note on interest parity and the supply of arbitrage funds. Journal of Political Economy 78, 540-545.

Roll, R., Yan, S., 2000. An explanation of the forward premium 'puzzle'. European Financial Management 6, 121-148.

Shen, P., 1998. How important is the inflation risk premium. Federal Reserve Bank of Kansas City, Economic Review, Fourth Quarter, 36-47.

Shleifer, A., Vishny, R., 1997. The limits of arbitrage. Journal of Finance 52, 35-55.

Vayanos, D., Vila, J.-L., 2009. A preferred-habitat model of the term structure of interest rates. NBER Working Paper No. W15487.

Verdelhan, A., 2010, A habit-based explanation of the exchange rate risk premium. Journal of Finance 65, 123-146.

Vives, X., 1995. Short-term investment and the information efficiency of the market. Review of Financial Studies 8, 125-160.

Wagner, C., 2008. Risk-premia, carry-trade dynamics, and speculative efficiency of currency markets. Unpublished working paper. Vienna University of Economics and Business Administration.

Wang, A., Zheng, L., 2008. Aggregate hedge fund flows and asset returns. Unpublished working paper. University of California, Irvine. 


\section{Table 1}

Descriptive statistics

Panel A gives the means, standard deviations, medians, and the 25th and the 75th percentiles of the variables used in this study. Panel B presents the means for those currency-month observations that belong to the carry trade short or long portfolios, respectively. Interest rate is the one-month interbank interest rate, inflation forecast is based on Eq. (19), inflation risk is the annualized standard deviation of the error term of the inflation Eq. (19), money supply is M2 scaled by stock market capitalization, exchange rate and forward premium are expressed per an equalweighted basket of the other sample currencies, country specific hedge fund flow is the net flow of new assets to hedge funds, in dollars, scaled by the M2 money supply of the country, non-country specific hedge fund flow is the net flow of new assets to hedge funds, in dollars, scaled by the total M2 money supply of all the sample countries, carry trade is the monthly return to our carry trade strategy, risk-adjusted carry trade is the monthly return to Sharpe ratio ranking-based investment strategy, and hedge fund AUM is the assets under management of the hedge fund industry scaled by the total M2 money supply of the sample countries. $\Delta$ denotes monthly change in the variable. The sample period is from $1979 / 1$ through 2008/12 and the sample countries are Belgium, Canada, Euro area, France, Germany, Italy, Japan, the Netherlands, Switzerland, the United Kingdom, and the United States. All data are on a monthly frequency. The number of observations for country specific variables is 3,120 and for non-country specific variables, the number of observations is 360 .

\begin{tabular}{|c|c|c|c|c|c|}
\hline PANEL A: Descriptive statistic & Mean & Std. & $25 \%$ & Median & $75 \%$ \\
\hline \multicolumn{6}{|l|}{ Country specific } \\
\hline Interest rate & 0.0691 & 0.0465 & 0.0363 & 0.0597 & 0.0938 \\
\hline$\Delta$ Interest rate & -0.0002 & 0.0128 & -0.0024 & 0.0000 & 0.0014 \\
\hline Inflation forecast & 0.0366 & 0.0329 & 0.0170 & 0.0276 & 0.0456 \\
\hline$\Delta$ Inflation forecast & -0.0001 & 0.0037 & -0.0020 & 0.0000 & 0.0018 \\
\hline Inflation risk $^{1}$ & 0.0135 & 0.0141 & 0.0097 & 0.0116 & 0.0143 \\
\hline$\Delta$ Inflation risk ${ }^{2}$ & 0.0002 & 0.1600 & -0.0754 & -0.0387 & 0.0180 \\
\hline Money supply & 2.0477 & 3.6562 & 0.7599 & 1.2670 & 1.8429 \\
\hline$\Delta$ Money supply & -0.0042 & 0.0570 & -0.0367 & -0.0064 & 0.0253 \\
\hline$\Delta$ Exchange rate & 0.0000 & 0.0209 & -0.0112 & -0.0002 & 0.0110 \\
\hline Forward premium & 0.0000 & 0.0029 & -0.0018 & -0.0001 & 0.0016 \\
\hline$\Delta$ Forward premium & 0.0000 & 0.0011 & -0.0002 & 0.0000 & 0.0002 \\
\hline Hedge fund flow ${ }^{3}$ & 0.0035 & 0.0142 & -0.0003 & 0.0009 & 0.0040 \\
\hline \multicolumn{6}{|l|}{ Non-country specific } \\
\hline Risk-adjusted carry trade & 0.0034 & 0.0215 & -0.0049 & 0.0048 & 0.0147 \\
\hline Carry trade & 0.0047 & 0.0206 & -0.0050 & 0.0067 & 0.0172 \\
\hline Hedge fund AUM & 0.0192 & 0.0181 & 0.0036 & 0.0125 & 0.0325 \\
\hline Hedge fund flow $(\times 100)^{3}$ & 0.0158 & 0.0448 & -0.0015 & 0.0066 & 0.0321 \\
\hline \multirow[t]{2}{*}{ PANEL B: Means } & \multicolumn{3}{|c|}{ Risk-adjusted carry trade } & \multicolumn{2}{|c|}{ Carry trade } \\
\hline & & Short & Long & Short & Long \\
\hline Interest rate & & 0.0486 & 0.0877 & 0.0387 & 0.0982 \\
\hline$\Delta$ Interest rate & & -0.0012 & 0.0013 & -0.0002 & 0.0007 \\
\hline Inflation forecast & & 0.0339 & 0.0395 & 0.0204 & 0.0533 \\
\hline$\Delta$ Inflation forecast & & 0.0000 & -0.0003 & -0.0001 & -0.0002 \\
\hline Inflation risk $^{1}$ & & 0.0153 & 0.0111 & 0.0131 & 0.0141 \\
\hline$\Delta$ Inflation risk ${ }^{2}$ & & 0.0035 & -0.0097 & -0.0012 & 0.0032 \\
\hline Money supply & & 1.9647 & 2.1837 & 1.4849 & 3.2781 \\
\hline$\Delta$ Money supply & & -0.0046 & -0.0034 & -0.0023 & -0.0032 \\
\hline$\Delta$ Exchange rate & & 0.0009 & -0.0010 & 0.0000 & 0.0002 \\
\hline Forward premium & & -0.0018 & 0.0019 & -0.0029 & 0.0030 \\
\hline$\Delta$ Forward premium & & -0.0001 & 0.0001 & 0.0000 & 0.0001 \\
\hline Hedge fund flow ${ }^{3}$ & & 0.0035 & 0.0033 & 0.0040 & 0.0027 \\
\hline
\end{tabular}

1 The level of inflation risk is expressed as the annualized standard deviation of the error term of the inflation Eq. (19).

2 Changes in inflation risk and money supply are expressed as changes in the logarithmic value as they enter the regressions in this form.

3 The country specific hedge fund flow uses the country's M2 as the scaling variable, whereas the non-country specific flow uses the total M2 of all the sample countries. 


\section{Table 2}

Correlations with hedge fund returns

This table presents the correlations between currency carry trade returns and various hedge fund indexes. Results in column 1 are based on the risk-adjusted carry trade strategy, and results in column 2 are based on returns to the simple carry trade strategy. Monthly return data for the hedge fund indexes are from Credit Suisse/Tremont and span the period from 1994/1 through 2008/12 (180 observations), except for multi-strategy for which data begin in 1994/4 (177 observations). $t$-values are reported in parentheses for the test that the correlation is equal to zero.

\begin{tabular}{lrr}
\hline & $(1)$ & $(2)$ \\
\hline All hedge funds & 0.4029 & 0.3246 \\
& $(5.87)$ & $(4.58)$ \\
Fixed income arbitrage & 0.5779 & 0.4106 \\
& $(9.45)$ & $(6.01)$ \\
Global macro & 0.3608 & 0.2873 \\
& $(5.16)$ & $(4.00)$ \\
Multi-strategy & 0.3550 & 0.2495 \\
& $(5.02)$ & $(3.41)$ \\
\hline
\end{tabular}




\section{Table 3}

Carry trade factor in hedge fund index returns

This table presents the results of regressing returns of four hedge fund indexes on the seven risk factors introduced by Fung and Hsieh (2001) and currency carry trade returns. Results in columns 2, 5, 8 and 11 are based on returns to risk-adjusted carry trade strategy, and results in columns 3, 6, 9, and 12 are based on simple carry trade returns. Monthly return data for the hedge fund indexes are from Credit Suisse/Tremont and span the period from 1994/1 through 2008/12 (180 observations), except for multi-strategy for which data begin in 1994/4 (177 observations). Data for the Fung and Hsieh factors are available at http://faculty.fuqua.duke.edu/ dah7/HFRFData.htm. Heteroskedasticity- and autocorrelation- consistent $t$-values (Newey and West, 1987) are reported in parentheses.

\begin{tabular}{|c|c|c|c|c|c|c|c|c|c|c|c|c|}
\hline & \multicolumn{3}{|c|}{ All hedge funds } & \multicolumn{3}{|c|}{ Global macro } & \multicolumn{3}{|c|}{ Fixed income arbitrage } & \multicolumn{3}{|c|}{ Multi-strategy } \\
\hline & (1) & (2) & (3) & (4) & (5) & $(6)$ & (7) & $(8)$ & (9) & $(10)$ & (11) & (12) \\
\hline Constant & $\begin{array}{r}0.0055 \\
(4.56)\end{array}$ & $\begin{array}{r}0.0044 \\
(3.83)\end{array}$ & $\begin{array}{r}0.0042 \\
(3.66)\end{array}$ & $\begin{array}{r}0.0091 \\
(4.75)\end{array}$ & $\begin{array}{r}0.0075 \\
(3.73)\end{array}$ & $\begin{array}{r}0.0071 \\
(3.45)\end{array}$ & $\begin{array}{r}0.0040 \\
(3.48)\end{array}$ & $\begin{array}{r}0.0031 \\
(2.82)\end{array}$ & $\begin{array}{r}0.0033 \\
(2.77)\end{array}$ & $\begin{array}{r}0.0062 \\
(5.04)\end{array}$ & $\begin{array}{r}0.0058 \\
(4.71)\end{array}$ & $\begin{array}{r}0.0059 \\
(4.67)\end{array}$ \\
\hline Bond trend & $\begin{array}{r}-0.0294 \\
(-2.60)\end{array}$ & $\begin{array}{r}-0.0270 \\
(-2.50)\end{array}$ & $\begin{array}{r}-0.0263 \\
(-2.33)\end{array}$ & $\begin{array}{r}-0.0295 \\
(-1.88)\end{array}$ & $\begin{array}{r}-0.0260 \\
(-1.70)\end{array}$ & $\begin{array}{r}-0.0246 \\
(-1.50)\end{array}$ & $\begin{array}{r}-0.0158 \\
(-2.17)\end{array}$ & $\begin{array}{r}-0.0139 \\
(-1.93)\end{array}$ & $\begin{array}{r}-0.0141 \\
(-1.99)\end{array}$ & $\begin{array}{r}-0.0067 \\
(-0.64)\end{array}$ & $\begin{array}{r}-0.0052 \\
(-0.49)\end{array}$ & $\begin{array}{r}-0.0054 \\
(-0.51)\end{array}$ \\
\hline Currency trend & $\begin{array}{r}0.0099 \\
(1.34)\end{array}$ & $\begin{array}{r}0.0171 \\
(2.27)\end{array}$ & $\begin{array}{r}0.0181 \\
(2.51)\end{array}$ & $\begin{array}{r}0.0152 \\
(1.06)\end{array}$ & $\begin{array}{r}0.0257 \\
(1.85)\end{array}$ & $\begin{array}{r}0.0280 \\
(2.10)\end{array}$ & $\begin{array}{r}-0.0095 \\
(-1.56)\end{array}$ & $\begin{array}{r}-0.0040 \\
(-0.80)\end{array}$ & $\begin{array}{r}-0.0052 \\
(-1.02)\end{array}$ & $\begin{array}{r}0.0071 \\
(1.12)\end{array}$ & $\begin{array}{r}0.0100 \\
(1.72)\end{array}$ & $\begin{array}{r}0.0093 \\
(1.69)\end{array}$ \\
\hline Commodity trend & $\begin{array}{r}0.0182 \\
(1.63)\end{array}$ & $\begin{array}{r}0.0188 \\
(1.93)\end{array}$ & $\begin{array}{r}0.0206 \\
(2.12)\end{array}$ & $\begin{array}{r}0.0191 \\
(0.98)\end{array}$ & $\begin{array}{r}0.0200 \\
(1.14)\end{array}$ & $\begin{array}{r}0.0229 \\
(1.27)\end{array}$ & $\begin{array}{r}0.0085 \\
(1.20)\end{array}$ & $\begin{array}{r}0.0090 \\
(1.58)\end{array}$ & $\begin{array}{r}0.0098 \\
(1.54)\end{array}$ & $\begin{array}{r}0.0034 \\
(0.48)\end{array}$ & $\begin{array}{r}0.0037 \\
(0.57)\end{array}$ & $\begin{array}{r}0.0040 \\
(0.59)\end{array}$ \\
\hline Equity ma & $\begin{array}{r}0.2568 \\
(5.48)\end{array}$ & $\begin{array}{r}0.2714 \\
(6.66)\end{array}$ & $\begin{array}{r}0.2666 \\
(6.91)\end{array}$ & $\begin{array}{r}0.1414 \\
(1.70)\end{array}$ & $\begin{array}{r}0.1630 \\
(2.17)\end{array}$ & $\begin{array}{r}0.1567 \\
(2.19)\end{array}$ & $\begin{array}{r}-0.0047 \\
(-0.13)\end{array}$ & $\begin{array}{r}0.0067 \\
(0.21)\end{array}$ & $\begin{array}{r}0.0005 \\
(0.02)\end{array}$ & $\begin{array}{r}0.0398 \\
(1.27)\end{array}$ & $\begin{array}{r}0.0450 \\
(1.42)\end{array}$ & $\begin{array}{r}0.0419 \\
(1.38)\end{array}$ \\
\hline Size spread & $\begin{array}{r}0.1643 \\
(2.89)\end{array}$ & $\begin{array}{r}0.1507 \\
(2.72)\end{array}$ & $\begin{array}{r}0.1598 \\
(3.07)\end{array}$ & $\begin{array}{r}0.0471 \\
(0.70)\end{array}$ & $\begin{array}{r}0.0271 \\
(0.43)\end{array}$ & $\begin{array}{r}0.0400 \\
(0.67)\end{array}$ & $\begin{array}{r}-0.0052 \\
(-0.30)\end{array}$ & $\begin{array}{r}-0.0158 \\
(-0.94)\end{array}$ & $\begin{array}{r}-0.0077 \\
(-0.44)\end{array}$ & $\begin{array}{r}0.0226 \\
(0.83)\end{array}$ & $\begin{array}{r}0.0167 \\
(0.64)\end{array}$ & $\begin{array}{r}0.0212 \\
(0.78)\end{array}$ \\
\hline Bond market & $\begin{array}{r}-0.0191 \\
(-3.20)\end{array}$ & $\begin{array}{r}-0.0118 \\
(-1.84)\end{array}$ & $\begin{array}{r}-0.0197 \\
(-3.75)\end{array}$ & $\begin{array}{r}-0.0378 \\
(-4.77)\end{array}$ & $\begin{array}{r}-0.0269 \\
(-3.50)\end{array}$ & $\begin{array}{r}-0.0386 \\
(-5.13)\end{array}$ & $\begin{array}{r}-0.0207 \\
(-4.15)\end{array}$ & $\begin{array}{r}-0.0149 \\
(-3.04)\end{array}$ & $\begin{array}{r}-0.0210 \\
(-4.48)\end{array}$ & $\begin{array}{r}-0.0086 \\
(-1.73)\end{array}$ & $\begin{array}{r}-0.0054 \\
(-1.10)\end{array}$ & $\begin{array}{r}-0.0086 \\
(-1.80)\end{array}$ \\
\hline Credit spread & $\begin{array}{r}-0.0261 \\
(-2.84)\end{array}$ & $\begin{array}{r}-0.0085 \\
(-0.80)\end{array}$ & $\begin{array}{r}-0.0172 \\
(-2.28)\end{array}$ & $\begin{array}{r}-0.0380 \\
(-2.48)\end{array}$ & $\begin{array}{r}-0.0120 \\
(-0.70)\end{array}$ & $\begin{array}{r}-0.0240 \\
(-1.93)\end{array}$ & $\begin{array}{r}-0.0651 \\
(-5.38)\end{array}$ & $\begin{array}{r}-0.0513 \\
(-6.00)\end{array}$ & $\begin{array}{r}-0.0603 \\
(-5.21)\end{array}$ & $\begin{array}{r}-0.0421 \\
(-4.75)\end{array}$ & $\begin{array}{r}-0.0350 \\
(-4.38)\end{array}$ & $\begin{array}{r}-0.0397 \\
(-4.49)\end{array}$ \\
\hline Currency speculation & & $\begin{array}{r}0.2992 \\
(3.63)\end{array}$ & $\begin{array}{r}0.3054 \\
(3.58)\end{array}$ & & $\begin{array}{r}0.4417 \\
(2.93)\end{array}$ & $\begin{array}{r}0.4786 \\
(2.83)\end{array}$ & & $\begin{array}{r}0.2346 \\
(4.65)\end{array}$ & $\begin{array}{r}0.1640 \\
(2.75)\end{array}$ & & $\begin{array}{r}0.1227 \\
(2.20)\end{array}$ & $\begin{array}{r}0.0840 \\
(1.14)\end{array}$ \\
\hline$R$-squared & 0.468 & 0.535 & 0.532 & 0.187 & 0.271 & 0.276 & 0.502 & 0.574 & 0.534 & 0.298 & 0.322 & 0.309 \\
\hline Monthly observations & 180 & 180 & 180 & 180 & 180 & 180 & 180 & 180 & 180 & 177 & 177 & 177 \\
\hline
\end{tabular}




\section{Table 4}

Returns to carry trades and hedge fund flows

This table gives the results of regressing monthly returns to currency carry trades on proxies of the number of speculators and changes therein. Results in columns 1 and 2 are based on returns to a risk-adjusted carry trade strategy, and results in columns 3 and 4 are based on returns to a simple carry trade strategy. The proxy for the number of speculators is the total hedge fund assets under management (AUM) scaled by the total M2 money supply of the sample countries. The proxy for changes in the number of speculators is the net flow of new funds to hedge funds, scaled by the total M2 money supply of the sample countries. Mkt-R, $H M L$, and $S M B$ are the three Fama and French (1993) risk factors. The sample period is from 1979/1 through 2008/12. Heteroskedasticity and autocorrelation consistent $t$-values (Newey and West, 1987) are reported in parentheses.

\begin{tabular}{lrrrr}
\hline Dependent: carry trade return & $(1)$ & $(2)$ & $(3)$ & $(4)$ \\
\hline Constant & 0.0053 & 0.0045 & 0.0073 & 0.0067 \\
& $(3.29)$ & $(2.73)$ & $(4.75)$ & $(4.38)$ \\
Hedge fund flow & 10.1932 & 8.9559 & 8.9945 & 8.1611 \\
& $(1.69)$ & $(1.70)$ & $(3.75)$ & $(3.47)$ \\
Hedge fund AUM $(t-1)$ & -0.1832 & -0.1609 & -0.2133 & -0.1967 \\
& $(-1.90)$ & $(-1.85)$ & $(-3.57)$ & $(-3.35)$ \\
Mkt-Rf & & 0.0640 & & 0.0486 \\
& & $(1.64)$ & & $(1.88)$ \\
SMB & & -0.0045 & & 0.0188 \\
& & $(-0.10)$ & & $0.48)$ \\
HML & & 0.0714 & & 0.0380 \\
& & $(1.59)$ & & $(0.93)$ \\
\hline$R$-squared & 0.053 & 0.068 & 0.056 & 0.065 \\
Monthly observations & 360 & 360 & 360 & 360 \\
\hline
\end{tabular}




\section{Table 5}

Changes in interest rates, inflation risk, money supply and hedge fund flows

This table gives the results of regressing monthly changes in interest rates on lagged changes in interest rate, changes in forecasted inflation, logarithm of inflation risk (fitted value from a GARCH(1,1) model on monthly inflation), logarithm of money supply (M2 divided by stock market capitalization), and hedge fund flow (scaled by M2 money supply). Hedge fund flow is interacted with the position variable (equal to one if the country is in the long portfolio during the month, negative one if the country is in the short portfolio during the month, and zero otherwise) to allow for opposite effects for high and low Sharpe ratio (or interest rate) countries. The position variable in column 1 is based on Sharpe ratio ranking, and in column 2 on interest rate ranking. The sample period is from 1979/1 through 2008/12 and the sample countries are Belgium, Canada, Euro area, France, Germany, Italy, Japan, the Netherlands, Switzerland, the United Kingdom, and the United States. Country and month fixed effects are included in the estimation. Heteroskedasticity and autocorrelation consistent $t$-values (Arellano, 1987) are reported in parentheses.

\begin{tabular}{lrr}
\hline Dependent: $\Delta$ interest rate & $(1)$ & $(2)$ \\
\hline$\Delta$ Interest rate $(t-1)$ & -0.3197 & -0.3133 \\
& $(-9.30)$ & $(-9.34)$ \\
$\Delta$ Inflation forecast & 0.0997 & 0.0741 \\
& $(2.24)$ & $(1.68)$ \\
$\Delta$ Log(inflation risk) & 0.0014 & 0.0007 \\
& $(2.15)$ & $(1.32)$ \\
$\Delta$ Log(money supply) & 0.0153 & 0.0161 \\
& $(2.19)$ & $(2.31)$ \\
Position $\times$ Hedge fund flow & -0.0366 & -0.0292 \\
& $(-3.78)$ & $(-2.76)$ \\
Position & 0.0024 & 0.0019 \\
& $(3.79)$ & $(4.14)$ \\
Hedge fund flow & -0.0218 & -0.0192 \\
& $(-1.87)$ & $(-1.75)$ \\
\hline$R$-squared & 0.288 & 0.278 \\
Monthly observations & 3,120 & 3,120 \\
\hline
\end{tabular}




\section{Table 6}

Changes in exchange rates and number of speculators

This table gives the results of regressing monthly changes in spot exchange rates on the level of forward premium, the change in forward premium, and hedge fund flow (scaled by M2 money supply). Hedge fund flow is interacted with the position variable (equal to one if the country is in the carry trade long portfolio during the month, minus one if the country is in the carry trade short portfolio during the month, and zero otherwise) to allow for opposite effects for high and low Sharpe ratio (or interest rate) currencies. The position variable in column 1 is based on Sharpe ratio ranking, and in column 2 on interest rate ranking. The spot exchange rate change is calculated for each currency as a change in the value of the currency against a basket containing all the other currencies in the sample. Hence, a positive (negative) change indicates appreciation (depreciation) of the currency. The sample period is from 1979/1 through 2008/12 and the sample countries are Belgium, Canada, Euro area, France, Germany, Italy, Japan, the Netherlands, Switzerland, the United Kingdom, and the United States. Country fixed effects are included in the estimation. Heteroskedasticity and autocorrelation consistent $t$-values (Arellano, 1987) are reported in parentheses.

\begin{tabular}{lrr}
\hline Dependent: $\Delta$ exchange rate & $(1)$ & $(2)$ \\
\hline Forward premium $(t-1)$ & 0.6226 & 0.4620 \\
& $(1.70)$ & $(1.34)$ \\
$\Delta$ Forward premium & 1.2247 & 1.1491 \\
& $(2.27)$ & $(2.01)$ \\
Position $\times$ Hedge fund flow & 0.0466 & 0.0941 \\
& $(2.71)$ & $(2.21)$ \\
Position & 0.0017 & 0.0023 \\
& $(3.19)$ & $(2.07)$ \\
Hedge fund flow & 0.0177 & 0.0439 \\
& $(0.64)$ & $(1.41)$ \\
\hline$R$-squared & 0.015 & 0.016 \\
Monthly observations & 3,120 & 3,120 \\
\hline
\end{tabular}


Fig. 1

Historical development of hedge fund assets under management. This figure shows the monthly development of the hedge fund industry's total assets under management (AUM) divided by the total M2 money supply of the sample countries (Belgium, Canada, Euro area, France, Germany, Italy, Japan, the Netherlands, Switzerland, the United Kingdom, and the United States) from 1979/1 to 2008/12.

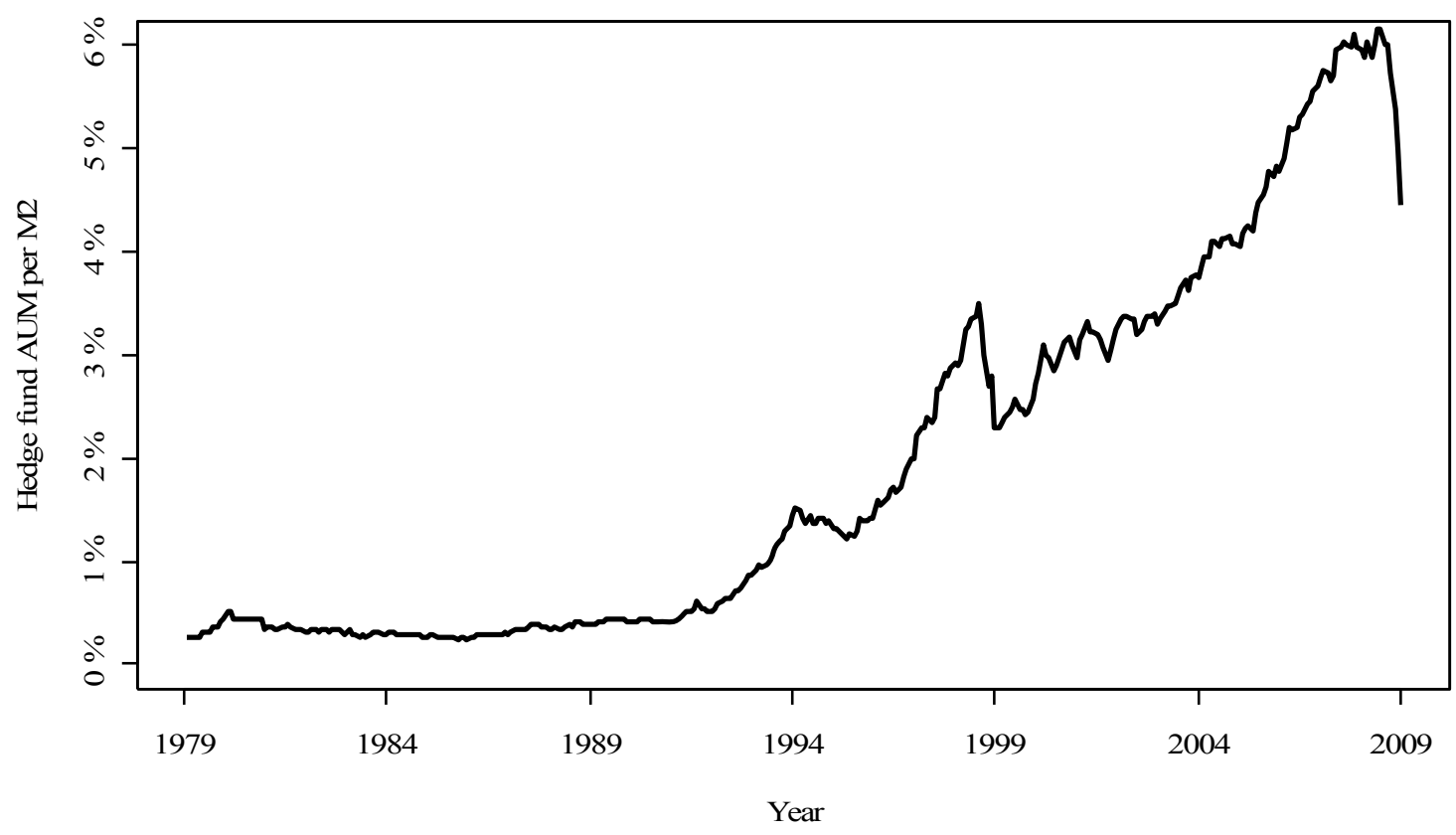

Sources: Hennessee, HFR, Lipper TASS, authors' estimates (see Appendix B for details). 
Fig. 2

Cumulative performance of carry trade strategies. This figure shows the cumulative return, in British pounds, to a constant $£ 100$-size investment in carry trade strategies from 1979/1 to 2008/12. The bold lines present the cumulative carry trade returns and the dotted lines present second-order polynomial trends fitted to the cumulative return data.

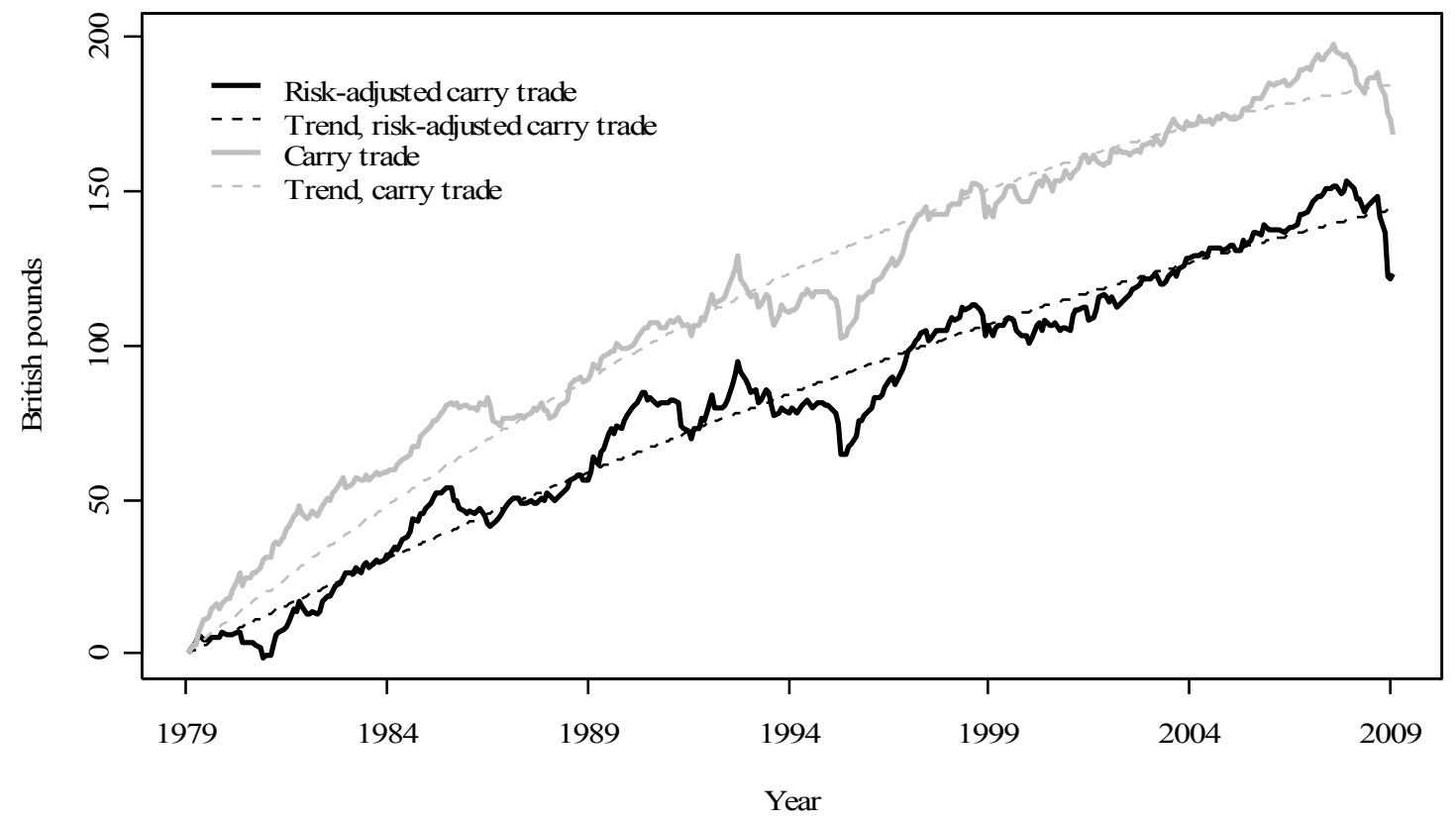


Fig. 3

Carry trade performance and hedge fund assets under management. This figure shows the monthly mean returns (black bar, left scale) and Sharpe ratios (grey bar, right scale) of the two carry trade strategies when the total hedge fund assets under management has been below USD 100 billion (1979-1992), between USD 100 billion and USD 500 billion (1993-2000), and above USD 500 billion (2001-2008).

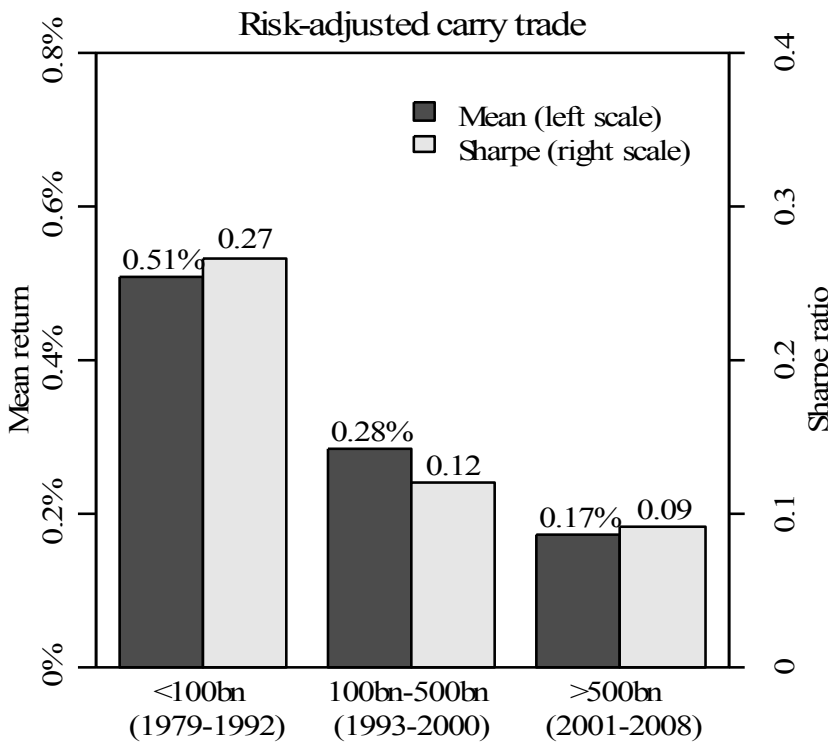

Hedge fund AUM, USD

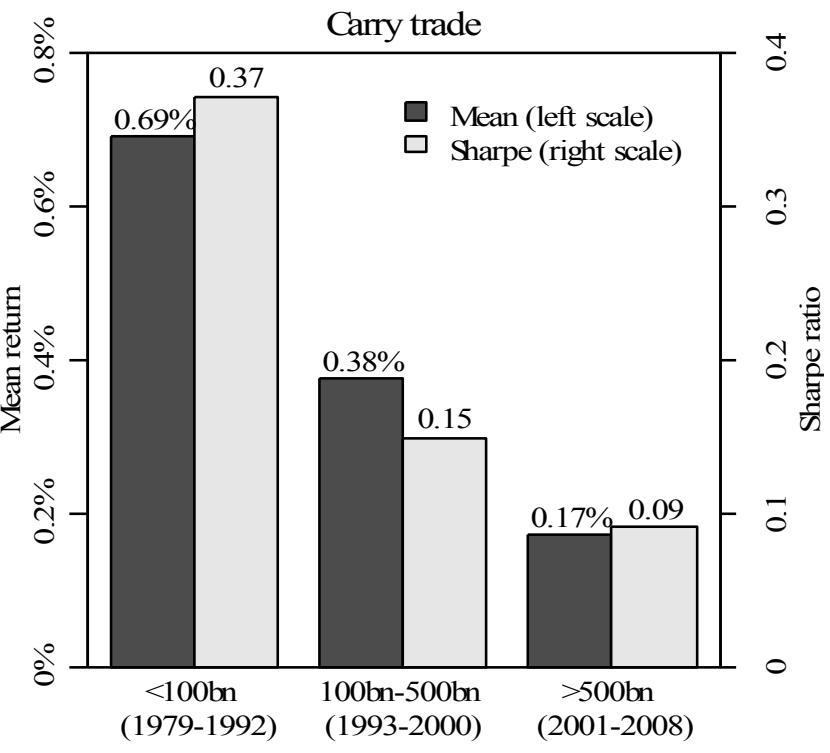

Hedge fund AUM, USD 
Fig. 4

Sharpe ratios of fixed income investments. This figure shows the development of the average Sharpe ratios of the onemonth fixed income securities in long and short countries of the two carry trade strategies. The Sharpe ratio is defined as the nominal return on the fixed income asset minus expected inflation divided by the standard deviation of unexpected inflation. To smooth out random noise, the graphs depict five-year moving averages of the Sharpe ratios. The sample period is from 1984/1 through 2008/12.
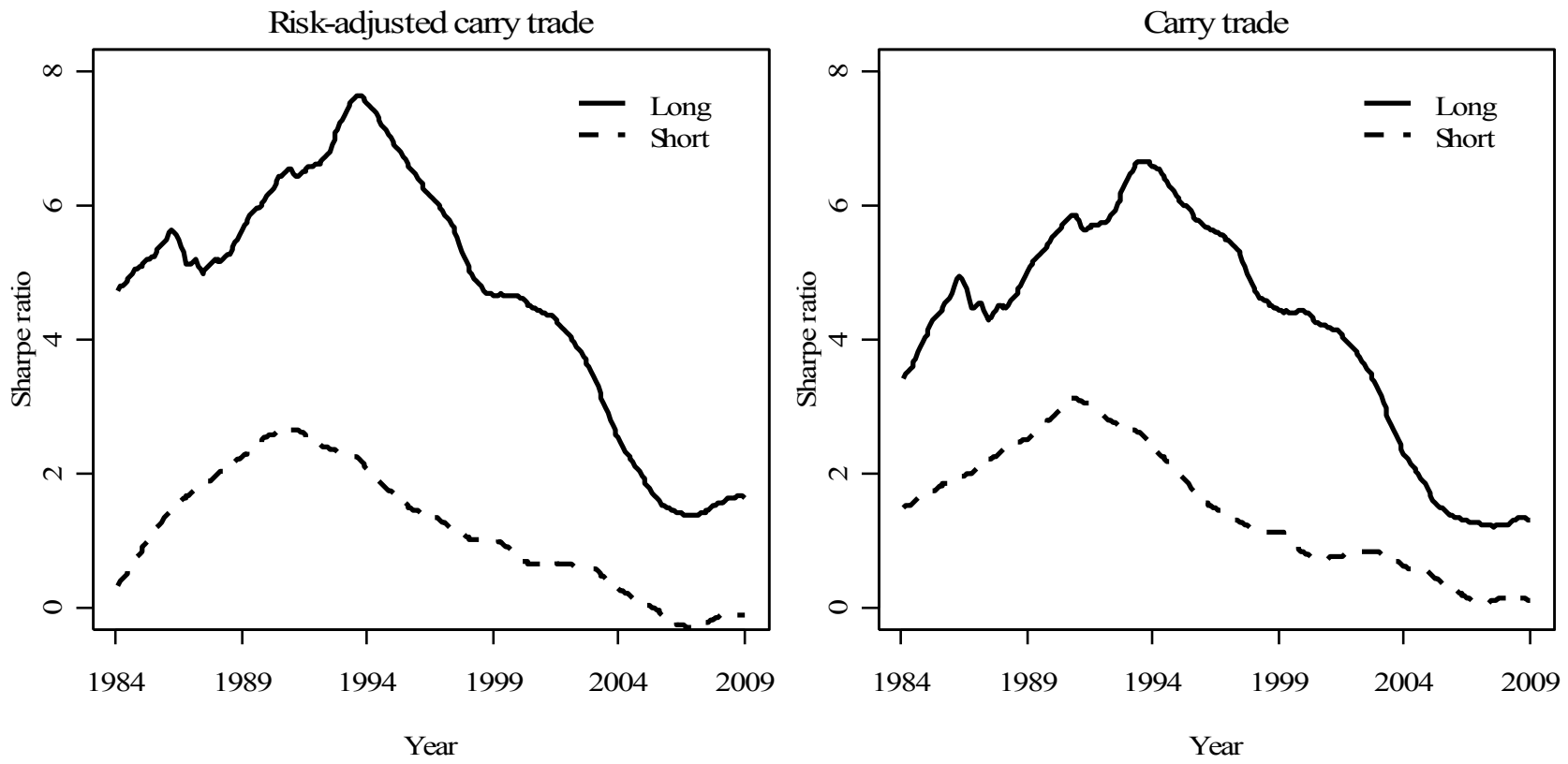